


\section{Effect of floor type on the ammonia and odour emission from veal calves housing}

J. Mosquera, T. van Hattum, G.M. Nijeboer, J.M.G. Hol, H.J.C. van Dooren, S. Bokma 
Mosquera, J., T. van Hattum, G.M. Nijeboer, J.M.G. Hol, H.J. van Dooren, S. Bokma, 2017. Effect of floor type on the ammonia and odour emission from veal calves housing. Wageningen Livestock Research, Report 980.

\section{Samenvatting NL}

In dit rapport worden de resultaten gepresenteerd van metingen die in opdracht van Productschap Vlees en Vee (PVV) en ICE/Beerepoot op twee bedrijven voor vleeskalveren zijn uitgevoerd volgens de case-control benadering om het effect van verschillende roostervloeren op de emissies van ammoniak en geur te bepalen. Ammoniakemissies waren significant lager voor "Groene vlag" met kleppen, en niet significant verschillend voor "Groene vlag" zonder kleppen en voor "EasyFix", ten opzichte van de traditionele houten roostervloer die ook gemeten is op deze bedrijven (control-case benadering). Geuremissies waren niet significant verschillend voor "Groene vlag" met kleppen, "Groene vlag" zonder kleppen en "EasyFix" ten opzichte van de traditionele houten roostervloer die gemeten is op deze bedrijven (control-case benadering).

\section{Summary UK}

This report presents the results of measurements performed at two animal facilities for veal calves using the control-case approach, to estimate the ammonia and odour emission reduction of a number of floors compared to the traditional wooden slatted floor. These measurements were commissioned by PVV (Productschap Vlees en Vee) and by ICE/Beerepoot. Ammonia emissions from the floor "Groene vlag" with valves were significantly lower, whereas from the floor "Groene vlag" without valves and from the floor "EasyFix" differences were not significant, when compared to the emission from the traditional floor measured simultaneously within the same farm (case-control approach). Odour emissions were not significant different for the floors "Groene vlag" with valves, "Groene vlag" without valves and "EasyFix" when compared to the emission from the traditional floor measured simultaneously within the same farm (case-control approach).

This report can be downloaded for free at http://dx.doi.org/10.18174/392090 or at www.wur.nl/livestock-research (under Wageningen Livestock Research publications).

\section{(C) 2017 Wageningen Livestock Research}

P.O. Box 338, 6700 AH Wageningen, The Netherlands, T +31 (0)317 483953 , E info.livestockresearch@wur.nl, www.wur.nl/livestock-research. Wageningen Livestock Research is part of Wageningen University \& Research.

All rights reserved. No part of this publication may be reproduced and/or made public, whether by print, photocopy, microfilm or any other means, without the prior permission of the publisher or author.

The ISO 9001 certification by DNV underscores our quality level. All our research commissions are in line with the Terms and Conditions of the Animal Sciences Group. These are filed with the District Court of Zwolle.

\footnotetext{
Wageningen Livestock Research Report 980
} 


\section{Table of contents}

$\begin{array}{ll}\text { Foreword } & 5\end{array}$

$\begin{array}{ll}\text { Summary } & 7\end{array}$

1

$\begin{array}{ll}\text { Introduction } & 9\end{array}$

2

$\begin{array}{lr}\text { Material and methods } & 10\end{array}$

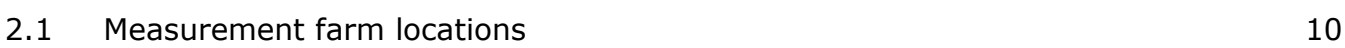

2.1.1 Farm location $1 \quad 10$

2.1.2 Farm location $2 \quad 11$

2.1.3 Working (emission reduction) principle 12

2.2 Measurements 13

2.2.1 Measurement strategy 13

2.2.2 Ammonia concentration 13

2.2.3 Odour concentration 14

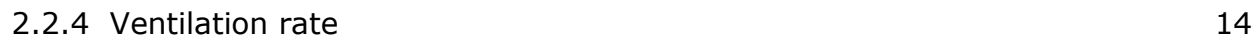

2.2.5 Temperature and relative humidity $\quad 15$

2.2.6 Production data and agronomic conditions $\quad 15$

2.2.7 Cleanliness of floor and animals 16

2.3 Data analysis $\quad 16$

2.3.1 Ammonia emissions 16

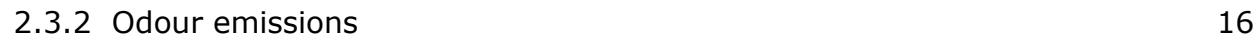

$\begin{array}{ll}2.3 .3 \text { Emission reduction } & 17\end{array}$

$\begin{array}{ll}2.3 .4 \text { Statistical analysis } & 17\end{array}$

$\begin{array}{llr}3 & \text { Results and discussion } & 18\end{array}$

3.1 Technical results and agronomic requirements $\quad 18$

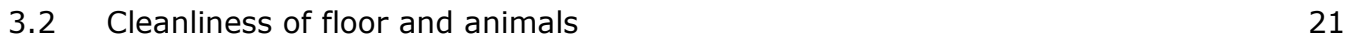

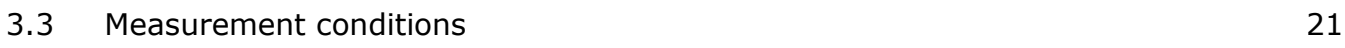

$\begin{array}{lll}3.4 & \text { Ammonia and odour emissions } & 25\end{array}$

4

$\begin{array}{ll}\text { Conclusions } & \mathbf{3 0}\end{array}$

$\begin{array}{ll}\text { References } & 31\end{array}$

Appendix 1 Photos of the farm locations 32

$\begin{array}{ll}\text { Appendix } 2 \text { Veterinary care } & 37\end{array}$ 


\section{Foreword}

The Dutch Ministry of Economic Affairs, together with the veal calves sector and the Dutch Society for the Protection of Animals, approved a research project focusing on the behavioural, veterinary, environmental and economic effects of using soft walking floors for veal calves instead of the commonly used wooden or concrete slats. This report presents the environmental effects, the results of measurements on ammonia and odour emissions performed at two animal facilities for veal calves using the control-case approach.

The research project was funded by the PVV (Dutch Meat and Livestock Board), and partly by ICE/Beerepoot. We thank the farmers participating in this research for providing the rooms/compartments to be measured, for their cooperation, and for supplying the necessary information on agronomic requirements.

Julio Mosquera

Project leader 


\section{Summary}

This report presents the results of environmental measurements performed at two animal facilities for veal calves using the control-case approach, to estimate the ammonia and odour emission reduction of three floor types compared to the traditional wooden slatted floor:

- $\quad$ "Groene Vlag" slatted floor (Irish Custom Extruders/Beerepoot stalinrichtingen)

- $\quad$ "Groene Vlag" slatted floor with valves in the slots (Irish Custom Extruders/Beerepoot stalinrichtingen)

- $\quad$ Easyfix Veal Slat rubber system

On each farm four identical, mechanically ventilated compartments were used, each accommodated with one of the four slatted floors. During the experiment all in - all out was performed for all compartments at the same time. Management and feeding were kept identical.

Ammonia and odour were measured six times in a year using a 24 hours continuous measuring strategy at approximately 2 months interval. This measuring strategy is in accordance with the Dutch emission measurement protocol (Ogink et al., 2013) and the international VERA protocol (http://www.veracert.eu).

Based on all available data, the following emission reductions (emission of the floor compared to the emission from the traditional wooden slatted floor as simultaneously measured at the same farm location; average of all measurements) were measured:

\begin{tabular}{lcc} 
Floor & average reductiont standard error of the means \\
& $\begin{array}{c}\text { Ammonia } \\
\text { (\% reduction) }\end{array}$ & $\begin{array}{c}\text { Odour } \\
\text { (Geduction) }\end{array}$ \\
\cline { 2 - 3 } "Groene vlag" with valves & $22.3 \pm 5.5$ & $12.5 \pm 14.7$ \\
\hline "Groene vlag" without valves & $5.5 \pm 2.6$ & $-11.1 \pm 12.5$ \\
\hline EasyFix & $-4.2 \pm 2.9$ & $-16.6 \pm 14.8$ \\
\hline
\end{tabular}

Ammonia emissions from the floor "Groene vlag" with valves were significantly lower (22.3\% lower; Pvalue: 0.03), whereas measured means from the floors "Groene vlag" without valves (5.5\% lower) and "EasyFix" (4.2\% higher) were not significantly different ( $P$-value: $>0.10$ ) when compared to the emission from the traditional floor measured simultaneously within the same farm (case-control approach).

Odour emissions from all measured floors ("Groene vlag" with valves, $12.5 \%$ lower ; "Groene vlag" without valves, $11.1 \%$ higher; "EasyFix", 16.6\% higher) were not significantly different ( $P$ value $>0.10$ ) when compared to the emission from the traditional floor measured simultaneously within the same farm (case-control approach). 


\section{Introduction}

The Ministry of Economic Affairs, together with the veal calves sector and the Dutch Society for the Protection of Animals ("Dierenbescherming") approved a research project focusing on the positive effects on welfare of soft walking floors for veal calves. This research project specified two phases with two different main objectives:

1. The first phase main's objective was to determine whether soft floors have a positive effect on the behaviour of animals as well as veterinary benefits compared to the wooden slatted floors usually applied for veal calves. This phase aimed also to identify and select the two best performing soft floor types for the second phase.

2. The second phase focussed on the determination of the potential positive effects of using soft floors when looking at the technical and economic value of floors. For this purpose, at a number of animal facilities, different rooms (that were provided with the selected floors) have been investigated and compared to a traditional reference (control) floor.

One of the possible positive side effects of applying this type of floors is that it may lead to a reduction of the ammonia and odour emission from the animal house. This would certainly stimulate the implementation of these floors in practice. The Steering Group "Floors for veal calves" asked WUR-LR to determine this effect by using the standard measurement protocol for ammonia (Ogink et al., 2013). This protocol is accepted by the Technical Advisory Commission (Tac-Rav) to determine emission factors for ammonia, factors that may be then included in Annex 1 of the Rav (Regeling ammoniak en veehouderij). For the measurement of the odour emissions, the standard measurement protocol for odour (Ogink, 2011) is applied.

This report presents the results of measurements performed to determine official emission factors for ammonia and odour for the different types of floors being considered in this project, including:

- Wooden slatted floor (slats are approximately $80 \mathrm{~mm}$ wide, slots are approximately $30 \mathrm{~mm}$ wide), used as reference (control) floor.

- $\quad$ "Groene Vlag" slatted floor (slats are approximately $130 \mathrm{~mm}$ wide, and provided with a convex compressible top layer; slots are approximately $29 \mathrm{~mm}$ wide).

- $\quad$ Easyfix slatted floor for veal calves (slats are approximately $120 \mathrm{~mm}$ wide, provided with a convex rubber layer; slots are approximately $30 \mathrm{~mm}$ wide).

- $\quad$ "Groene Vlag" slatted floor with valves (slats are approximately $130 \mathrm{~mm}$ wide, and provided with a convex compressible top layer; slots are approximately $29 \mathrm{~mm}$ wide), with valves in de slots. 


\section{Material and methods}

In the following paragraphs and annexes, a description will be given of the measurement farm locations and housing systems (2.1; Annex 1$)$, of the measurement setup and strategy (2.2), and of the method of processing the data (2.3).

\subsection{Measurement farm locations}

\subsubsection{Farm location 1}

The measurements took place in four rooms/compartments of an animal building (in use for more than one decade) used for the production of white veal calves. All four rooms were identical in design (6.8 $\mathrm{m}$ wide and $15 \mathrm{~m}$ long), and consisted of two rows of four pens $(2.5 \mathrm{~m} \times 3.6 \mathrm{~m}$ ) separated by a feeding alley (Annex 1). Each pen had a capacity for five calves ( 8 pens $\times 5$ calves $=40$ animal places). This is in accordance to the existing regulation prescribing at least $1.8 \mathrm{~m}^{2}$ walking area per animal. Manure is stored in manure pits under the slatted floors (depth of approximately $50 \mathrm{~cm}$ ).

The calves are placed in the rooms at approximately two weeks of age, with an average initial weight of approximately $45 \mathrm{~kg}$. In accordance to the existing regulations for veal calves, animals are first kept in individual boxes, and placed in groups at an age of 8 weeks until the animals reach a slaughter weight of approximately $225 \mathrm{~kg}$. The production cycle was on average 185 days (average of the two measured production cycles for the four measured rooms).

The rooms are at the very beginning of the production cycle naturally ventilated, by regulating the inlet openings, and later on force ventilated: air enters the room through an inlet opening (Annex 1) and leaves the room via ventilation shafts placed on top of the room above the feeding alley. For this purpose, each room is provided with one ventilation fan (45 cm diameter), controlled by a climate system.

The calves were fed twice a day at about half past seven in the morning and half past five in the afternoon. The calves were fed with water and milk powder combined with concentrates and small amounts of straw and alfalfa.

Within the framework of this study, the rooms were provided with different floors (see 2.1.3 for photos of the investigated slatted floors):

- Wooden slatted floor (slats are approximately $80 \mathrm{~mm}$ wide, slots are approximately $30 \mathrm{~mm}$ wide), used as reference (control) floor.

- $\quad$ "Groene Vlag" slatted floor (slats are approximately $130 \mathrm{~mm}$ wide, and provided with a convex compressible top layer; slots are approximately $29 \mathrm{~mm}$ wide).

- $\quad$ Easyfix slatted floor for veal calves (slats are approximately $120 \mathrm{~mm}$ wide, provided with a convex rubber top layer; slots is approximately $30 \mathrm{~mm}$ wide).

- $\quad$ "Groene Vlag" slatted floor with valves (slats are approximately $130 \mathrm{~mm}$ wide, and provided with a convex compressible top layer; slots are approximately $29 \mathrm{~mm}$ wide), with valves in de slots.

Table 1 provides an overview of the main characteristics of the different rooms. 


\begin{tabular}{|c|c|c|c|c|}
\hline Characteristics/room & 1 & 2 & 3 & 4 \\
\hline Number of pens & 8 & 8 & 8 & 8 \\
\hline $\begin{array}{l}\text { Pen dimension (width } \mathrm{x} \\
\text { length) }\end{array}$ & $2.5 \times 3.6$ & $2.5 \times 3.6$ & $2.5 \times 3.6$ & $2.5 \times 3.6$ \\
\hline Animal places & 40 & 40 & 40 & 40 \\
\hline Living space per animal $\left(\mathrm{m}^{2}\right)$ & 1.8 & 1.8 & 1.8 & 1.8 \\
\hline $\begin{array}{l}\text { Slatted floor (\% of living } \\
\text { space) }\end{array}$ & 100 & 100 & 100 & 100 \\
\hline Slatted floor type & $\begin{array}{l}\text { "Groene Vlag" } \\
\text { with valves }\end{array}$ & "Groene Vlag" & Easyfix & $\begin{array}{l}\text { Wooden slats } \\
\text { (traditional) }\end{array}$ \\
\hline Manure pit depth $(\mathrm{cm})$ & $50 \mathrm{~cm}$ & $50 \mathrm{~cm}$ & $50 \mathrm{~cm}$ & $50 \mathrm{~cm}$ \\
\hline $\begin{array}{l}\text { Ventilation fans: number } \\
\text { diameter }(\mathrm{cm}) \\
\text { Total max. capacity }\left(\mathrm{m}^{3} / \mathrm{h}\right)\end{array}$ & $\begin{array}{c}1 \\
45 \\
6000\end{array}$ & $\begin{array}{c}1 \\
45 \\
6000\end{array}$ & $\begin{array}{c}1 \\
45 \\
6000\end{array}$ & $\begin{array}{c}1 \\
45 \\
6000\end{array}$ \\
\hline
\end{tabular}

\subsubsection{Farm location 2}

The measurements took place in four rooms of an animal building (in use for more than one decade) used for the production of white veal calves. All four rooms were identical in design $(8.0 \mathrm{~m}$ wide and $22.7 \mathrm{~m}$ long), and consisted of two rows of six pens separated by a feeding alley (Annex 1). Per row, four small pens (see Table 2), have a capacity of six calves per pen. The other two larger pens (see Table 2) have a capacity for seven calves (in total 76 animal places). This is in accordance to the existing regulation prescribing at least $1.8 \mathrm{~m}^{2}$ walking area per animal. Manure is stored in manure pits under the slatted floors (depth of approximately $115 \mathrm{~cm}$ ).

The calves are placed in the rooms with an average initial weight of approximately $45 \mathrm{~kg}$. In accordance to the existing regulations for veal calves, animals are first kept in individual boxes, and placed in groups at an age of 8 weeks until the animals reach a weight of approximately $250 \mathrm{~kg}$. The production cycle was on average 203 days (average of the two measured production cycles for the four measured rooms).

The rooms are at the very beginning of the production cycle naturally ventilated, by regulating the inlet openings, and later on force ventilated: air enters the room through an inlet opening (Annex 1) and leaves the room via ventilation shafts placed on top of the room above the feeding alley. For this purpose, each room is provided with two ventilation fans ( $40 \mathrm{~cm}$ diameter), controlled by a climate system.

The calves were fed twice a day at about five in the morning and four in the afternoon. The calves were fed liquid feeding (warm milk made from water and milk powder) and additionally some roughage.

Within the framework of this study, the rooms were provided with different floors, similar as those described by farm location 1 .

Table 2 provides an overview of the main characteristics of the different rooms. 


\begin{tabular}{|c|c|c|c|c|}
\hline Characteristics/room & 2 & 3 & 6 & 5 \\
\hline Number of pens & 12 & 12 & 12 & 12 \\
\hline \multicolumn{4}{|l|}{ Pen dimension (width $\mathrm{x}$} & $3.64 \times 2.95$ \\
\hline Pen 1 & $3.55 \times 2.95$ & $3.55 \times 2.95$ & $3.55 \times 2.95$ & $3.55 \times 2.95$ \\
\hline Pen 2,3 en 4 & $4.15 \times 2.95$ & $4.15 \times 2.95$ & $4.25 \times 2.95$ & $4.25 \times 2.95$ \\
\hline Pen 5 & $4.42 \times 2.95$ & $4.42 \times 2.95$ & $4.28 \times 2.95$ & $4.28 \times 2.95$ \\
\hline \multicolumn{5}{|l|}{ Pen 6} \\
\hline Animal places & 76 & 76 & 76 & 76 \\
\hline Walking area per animal $\left(\mathrm{m}^{2}\right)$ & 1.8 & 1.8 & 1.8 & 1.8 \\
\hline $\begin{array}{l}\text { Slatted floor (\% of walking } \\
\text { area) }\end{array}$ & 100 & 100 & 100 & 100 \\
\hline Slatted floor type & $\begin{array}{l}\text { "Groene Vlag" } \\
\text { with valves }\end{array}$ & "Groene Vlag" & Easyfix & $\begin{array}{l}\text { Wooden slats } \\
\text { (traditional) }\end{array}$ \\
\hline Manure pit depth $(\mathrm{cm})$ & 117 & 115 & 115 & 115 \\
\hline Ventilation fans: number & 2 & 2 & 2 & 2 \\
\hline diameter $(\mathrm{cm})$ & 40 & 40 & 40 & 40 \\
\hline Total max capacity $\left(\mathrm{m}^{3} / \mathrm{h}\right)$ & 9000 & 9000 & 9000 & 9000 \\
\hline
\end{tabular}

\subsubsection{Working (emission reduction) principle}

The (soft)floors considered in this project (Figure 1) have been selected not only because they may have positive effects on the animals (increasing technical and economic value), but also because of their potential to reduce ammonia emissions from the animal building. The idea behind the expected reduction in ammonia emissions is:

- For all floors (excluding the traditional wooden slatted floor), using a convex top layer (rubber for the Easyfix and TPE for the "Groene vlag" floors) may favour fast removal of urine and faeces to the manure pit underneath the floor. By removing the urine to the pits with less favourable emission conditions the emission of ammonia will be reduced.

- For all floors (excluding the traditional wooden slatted floor), using non-porous materials may reduce the $\mathrm{pH}$ of the urine left on the slatted floor, and make the conditions less favourable for ammonia production.

- For the "Groene vlag with valves" slatted floor, it is expected that the valves will minimize air exchange between the manure pit underneath the floor, and the animal building, resulting in a reduction in ammonia emissions from the manure pit.
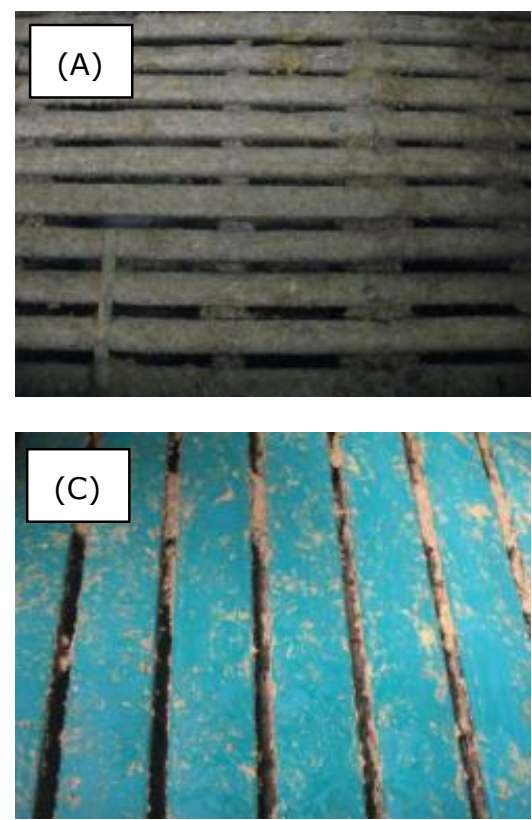
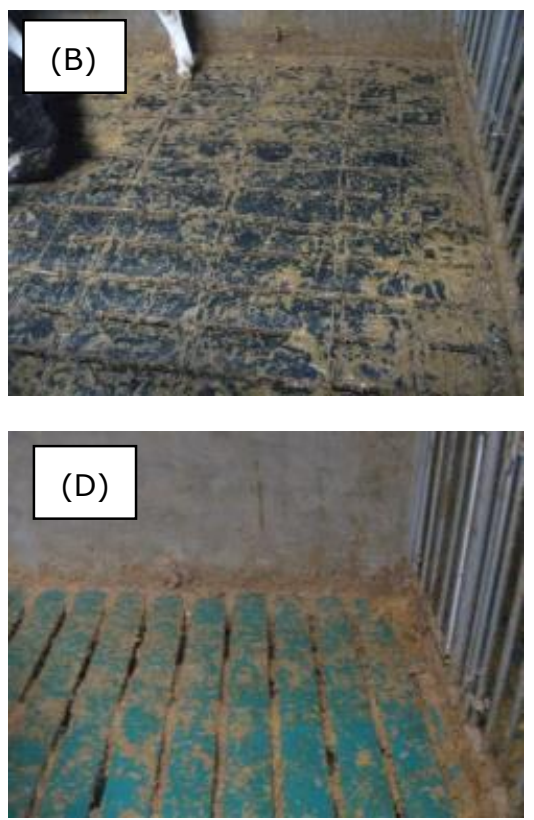

Figure 1 Selected slatted floors. A) Traditional wooden slatted floor; B) Easyfix; C)-D) "Groene vlag". 


\subsection{Measurements}

\subsubsection{Measurement strategy}

In this project, measurements were performed at two animal facilities for veal calves using the control-case approach. The all-in all-out approach was implemented, meaning that the rooms were simultaneously filled with animals at the beginning of each production cycle. Besides, at each animal facility management and veterinary care of the veal calves was similar for all the rooms being considered in this research project.

At each animal facility four rooms were taken into consideration, each with a particular type of floor being used to keep the veal calves, as described in section 2.1. The floors were installed in different rooms of the animal facilities in October 2013 for farm location 1, and in November 2013 for farm location 2. The reference floor used as control (wooden slats), already present in the animal facilities, had a good quality and did not need to be replaced. The rooms are forced ventilated except for the first few days of the rearing period.

Measurements were performed in the period February 2014- April 2015 for farm location 1, and in the period March 2014 - May 2015 for farm location 2, following the measurement protocol described in Ogink et al. (2013) for ammonia $\left(\mathrm{NH}_{3}\right)$, and in Ogink (2011) for odour. Shortly, these protocols specify the implementation of six measurements of at least 24 hours, evenly distributed in a calendar year (approximately every two months) and over the production cycle of the animals, taking into account the agronomic requirements as presented in the measurement protocols. For animals with a growing production cycle, and expected linear increase in ammonia emission during the production cycle, such as veal calves, the protocols also specify that:

- Per farm location and housing system, three of the six measurements should be performed in the first half of the production cycle, and the other three measurements in the second half of the production cycle.

- The measurements in the second half of the production cycle must be implemented over three different seasons.

For every measurement period, the following measurements (per farm location and floor type/room) were performed (see Annex 1 for schema with measuring points):

- The concentration of ammonia in the outgoing air (through the ventilation fans) and in the incoming air (background), using the method described in 2.2.2.

- The concentration of odour in the outgoing air (through the ventilation fans), using the method described in 2.2.3.

- The ventilation rate using the method described in 2.2.4.

- The temperature and relative humidity in all the measured rooms, and outside the rooms, using the method described in 2.2.5.

- $\quad$ Feeding and production data, agronomic requirements as described in 2.2.6.

- Visual inspection of the degree of cleanliness of the floor and the animals (see 2.2.7)

\subsubsection{Ammonia concentration}

The ammonia concentration in both the incoming (background) and outgoing (room) air was measured for all rooms in duplicate using gas washing (impingers, acid traps, acid scrubbers or absorption flasks; Wintjes, 1993). In this method, an air sample is taken and drawn at a known flow rate $(\sim 1,0$ I/min) using a pump (Thomas Industries Inc., model 607CD32, Wabasha, Minnesota ,VS) and critical orifices through a set of three absorption flasks (Figure 2). The first flask (filled with $100 \mathrm{ml} \mathrm{0,05} \mathrm{M}$ nitric acid) is for collecting the ammonia, the second one (also filled with $100 \mathrm{ml} \mathrm{0,05} \mathrm{M}$ nitric acid) to check for saturation, and the third one (empty) to collect any present liquids in the air before reaching the pump. The samples are analysed in a laboratory by using spectrophotometry. The flow rate through the acid traps is measured before and after performing the measurements by using a calibrated flow meter (Defender 510-m, Bios Int. Corp, USA). 

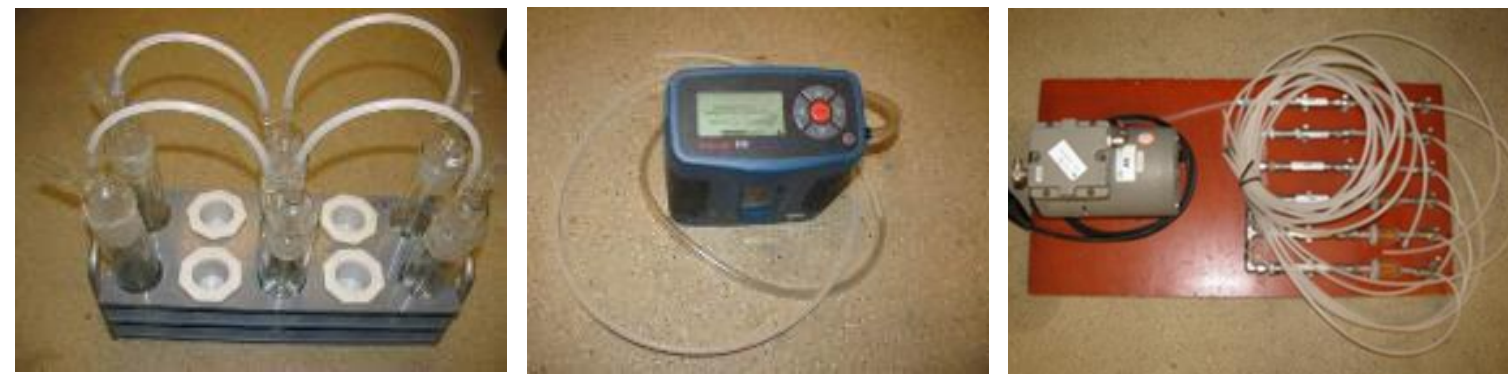

Figure 2 Measurement method for ammonia concentration measurements. Left: acid traps; Middle: flow meter; Right: pump.

\subsubsection{Odour concentration}

Odour concentrations in the outgoing (room) air were measured in all rooms using the lung method as described in Ogink and Mol (2002). In this method, a 40 litre Nalophan sampling bag is first inserted in a closed container and kept under vacuum conditions (Figure 3). An air sample is then taken from the sample location by using Teflon sampling lines, and sucking air from the container at a known flow rate $(\sim 0,4 \mathrm{l} / \mathrm{min})$ using a pump (Thomas Industries Inc., model 607CD32, Wabasha, Minnesota ,VS) and critical orifices. This creates an under pressure in the container, allowing the air sample to be drawn into the sampling bag, after first being led through a dust filter (type \#1130, diameter: $50 \mathrm{~mm}$, 1-2 $\mu \mathrm{m}$, Savillex ${ }^{\circledR}$ Corp., Minnetonka, VS). Odour samples were analysed within 24 hours after sampling by olfactometry by an accredited odour laboratory, following the European Normative EN 13725 (CEN, 2003). Unlike ammonia, odour concentrations are measured during a shorter period of time ( 2 hours, between 10:00am and 12:00 am, instead of 24 hours). For odour, single measurements (per room) were performed.

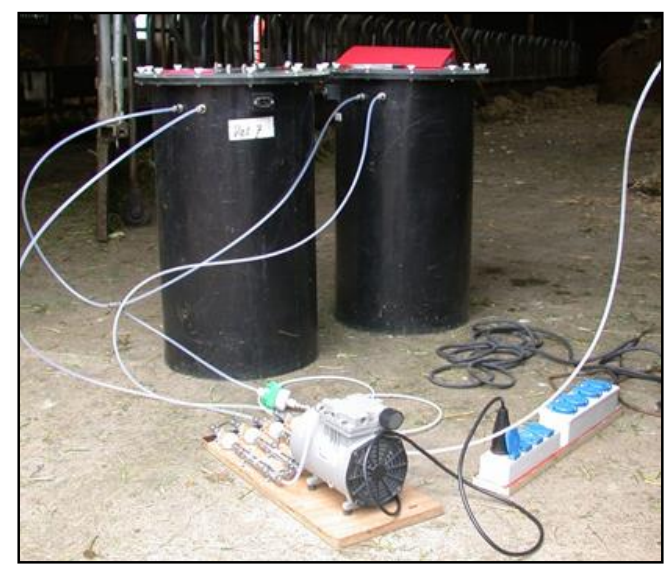

Figure 3 Measurement method for odour concentration measurements.

\subsubsection{Ventilation rate}

All rooms were force ventilated by means of a computer controlled ventilator. Ventilation rate was regulated by the ventilation computer, based on a temperature bodyweight algorithm. Actual ventilation was checked by means of a measuring fan. To determine the ventilation rate the signal of the measuring fan was registered and logged into a logging system during measurements. The characteristics of the measuring fans were available. Next to this all fans were additionally manually calibrated halfway the project. The procedure used to calibrate the ventilation fans was as follows:

1. The ventilation rate was set (through the computer system on farm) to different constant values, and the signal from the computer system logged into a logging system.

2. For the specified ventilation levels, the air speed through the ventilation shaft was measured at about $10 \mathrm{~cm}$ from the edge of the shaft (25\% of the shaft diameter). From this air speed and the surface of the shaft, a ventilation rate in $\mathrm{m}^{3} / \mathrm{h}$ was calculated.

3. Combining the data measured for all (similar) measured fans, a calibration line (ventilation rate vs. signal from the computer system) was determined (see Figure 4). 

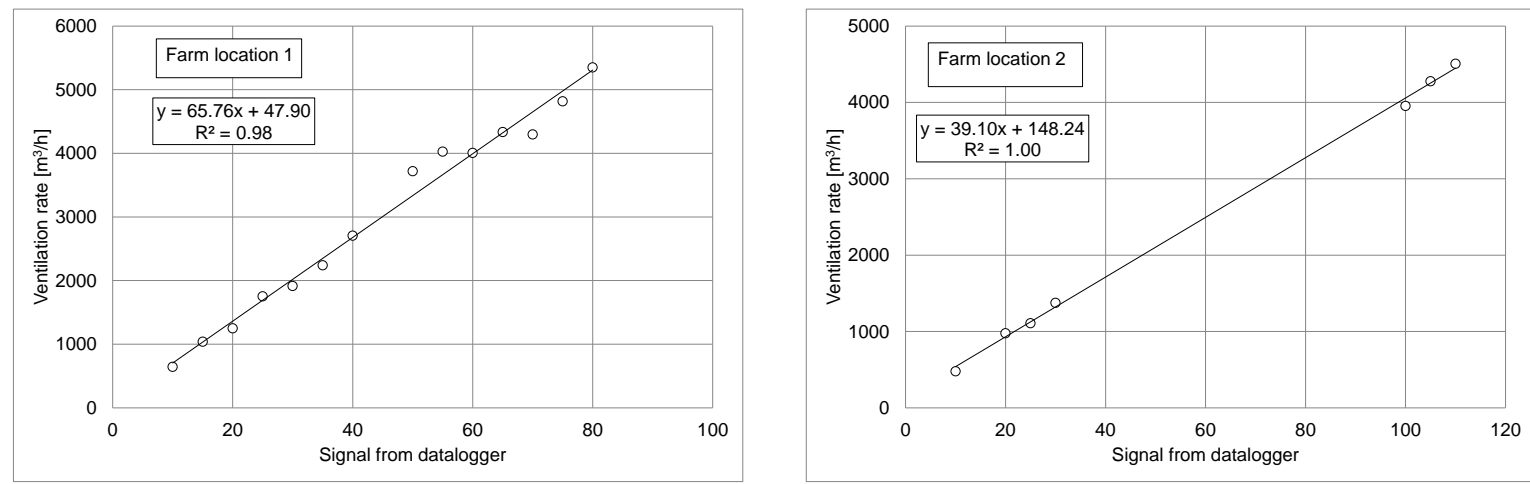

Figure 4 Calibration lines used to determine the ventilation rate.

\subsubsection{Temperature and relative humidity}

Room and outdoor temperatures and relative humidity were continuously measured by using temperature and relative humidity sensors (Rotronic; ROTRONIC Instrument Corp., Huntington, VS; Figure 5) with an accuracy of respectively $\pm 1,0^{\circ} \mathrm{C}$ en $\pm 2 \%$. Data was stored in a logging system (Campbell Scientific Inc., Logan, VS).

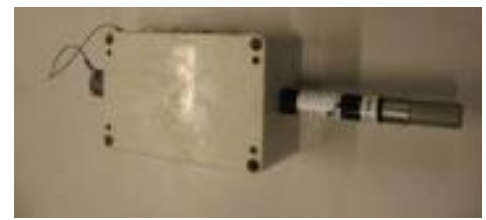

Figure 5 Rotronic for temperature and relative humidity measurements.

\subsubsection{Production data and agronomic conditions}

The following information about the production and agronomic conditions was collected:

- Number of animals (per room)

- Average weight of the animals

- Daily gain of the animals

- Feed composition

- $\mathrm{CO}_{2}$ concentration

At farm location 1, single measurements (per room) of carbon dioxide $\left(\mathrm{CO}_{2}\right)$ concentrations in the outgoing (room) air were performed in all rooms using the same lung principle as for odour concentrations. However, for $\mathrm{CO}_{2}$ concentrations air samples were taken by sucking air at a known flow rate of 0,02 l/min, using the same kind of pump (Thomas Industries Inc., model 607CD32, Wabasha, Minnesota ,VS) as for odour with different critical orifices. Air samples were then analysed in the lab by using a gas chromatograph (Interscience/Carlo Erba Instruments Inc., Breda, the Netherlands, GC 8000 Top; column Molsieve 5A; detector: HWD). As for ammonia, this method gives an average $\mathrm{CO}_{2}$ concentration over the whole measurement period ( 24 hours).

At farm location 2, carbon dioxide $\left(\mathrm{CO}_{2}\right)$ concentrations in the outgoing (room) air were measured in most of the cases also using the lung principle. In some cases, however, when not enough vessels were available, measurements were performed by using an infrared photoacoustic multi-gas monitor (Figure 6; INNOVA 1312, LumaSense Technologies, Ballerup, Denmark). 


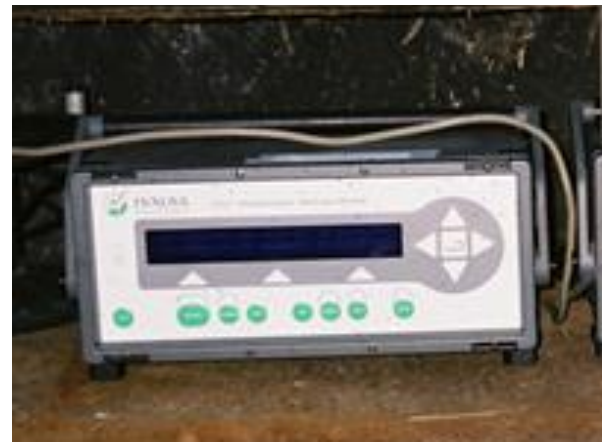

Figure 6 Infrared photoacoustic multi-gas monitor for $\mathrm{CO}_{2}$ concentration measurements.

\subsubsection{Cleanliness of floor and animals}

During each measuring period the cleanliness of the floors and animals was visually checked and rated according to the following scheme:

\begin{tabular}{cc} 
Code & Description \\
\hline 1 & Clean ( $<10 \%$ dirty $)$ \\
\hline 2 & Reasonably clean $(10-40 \%$ dirty $)$ \\
\hline 3 & Largely dirty $(40-70 \%$ dirty $)$ \\
\hline 4 & Dirty ( $>70 \%$ dirty $)$ \\
\hline
\end{tabular}

\subsection{Data analysis}

\subsubsection{Ammonia emissions}

Ammonia emissions $\left(E\left(\mathrm{NH}_{3}\right)_{\mathrm{ijk}}\right.$ in $[\mathrm{kg} /$ year per animal place]) per farm location $(\mathrm{i}=1,2)$, measurement period $(j=1,2, \ldots, 6)$ and treatment ( $k=1$ Traditional wooden slatted floor; 2 "Groene vlag" slatted floor; 3 "Easyfix" slatted floor; 4 "Groene vlag" slatted floor with valves), were calculated based on the measured ventilation rates $\left(\mathrm{V}_{\mathrm{ijk}}\right.$ in $\left[\mathrm{m}^{3} / \mathrm{h}\right]$; average over the 24-hour measurement period) and ammonia concentrations in the outgoing (Cout ${ }_{i j k}$ in $\left[\mathrm{g} / \mathrm{m}^{3}\right]$ average over the 24-hour measurement period) and incoming (background; $\mathrm{Cbackg}_{\mathrm{ijk}}$ in $\left[\mathrm{g} / \mathrm{m}^{3}\right]$; average over the 24-hour measurement period) air, the number of animal places in the measured rooms, and the regulatory percentage of the days the rooms are expected to be occupied ( $93 \%$ for white veal calves, implicating $7 \%$ of cleaning time between production cycles; Groenestein and Aarnink, 2008) according to:

$$
E\left(N_{3}\right)_{i j k}=V_{i j k} \times\left(C o u t_{i j k}-C_{b a c k g} i j k\right) \times \frac{1 \mathrm{~kg}}{1000 \mathrm{~g}} \times \frac{24 \mathrm{~h}}{1 \mathrm{~d}} \times \frac{365 \mathrm{~d}}{1 \text { year }} \times \frac{1}{\text { animalplaces }} \times 0.93
$$

Ammonia emissions per treatment and farm location $\left(\mathrm{E}\left(\mathrm{NH}_{3}\right)_{\mathrm{ik}}\right.$ in $[\mathrm{kg} /$ year per animal place]) were then calculated by averaging the emissions measured during the six measurement periods. Next, ammonia emissions per treatment $\left(\mathrm{E}\left(\mathrm{NH}_{3}\right)_{\mathrm{k}}\right.$ in $[\mathrm{kg} /$ year per animal place]) were calculated by averaging the emissions measured at the two farm locations.

\subsubsection{Odour emissions}

Odour emissions ( $E(\text { odour })_{i j k}$ in $\left[\mathrm{OU}_{E} / \mathrm{s}\right.$ per animal place]) per farm location $(i=1,2)$, measurement period $(j=1,2, \ldots, 6)$ and treatment $(k=1$. Traditional wooden slatted floor; 2 . "Groene vlag" slatted floor; 3. "Easyfix" slatted floor; 4. "Groene vlag" slatted floor with valves), were calculated based on the measured ventilation rates $\left(V_{i j k}\right.$ in $\left[\mathrm{m}^{3} / \mathrm{h}\right]$; average over the 2-hour measurement period), odour concentrations in the outgoing air (Cout ${ }_{i j k}$ in $\left[\mathrm{OU}_{\mathrm{E}} / \mathrm{m}^{3}\right]$ average over the 2-hour measurement period), the number of animal places in the measured rooms, and the regulatory percentage of the days the rooms are expected to be occupied ( $93 \%$ for white veal calves, implicating $7 \%$ of cleaning time between production cycles; Groenestein and Aarnink, 2008) according to: 
$E(\text { odour })_{i j k}=V_{i j k} \times$ Cout $_{i j k} \times \frac{1 \mathrm{~h}}{3600 \mathrm{~s}} \times \frac{1}{\text { animalplaces }} \times 0.93$

Odour emissions per treatment and farm location ( $\mathrm{E}$ (odour) $\mathrm{ik}$ in $\left[\mathrm{OU} \mathrm{U}_{\mathrm{E}} / \mathrm{s}\right.$ per animal place]) were then calculated as follows:

1. First, measured emissions were transformed into the natural logarithm scale.

2. Then, the average of these emissions (per treatment and farm location) was calculated.

3. Finally, the averaged Ln-emissions were transformed back into the normal scale, leading to a median (instead of average) emission per treatment and farm location.

Odour emissions per treatment ( $\mathrm{E}$ (odour) $)_{\mathrm{k}}$ in $\left[\mathrm{OU}_{\mathrm{E}} / \mathrm{s}\right.$ per animal place]) were then calculated by averaging the emissions measured at the two farm locations.

\subsubsection{Emission reduction}

The reduction in ammonia and odour emission per treatment ( $k=2$. "Groene vlag" slatted floor; 3. "Easyfix" slatted floor; 4. "Groene vlag" slatted floor with valves) compared to the traditional wooden slatted floor is calculated as follows:

1. First, the emission reduction for ammonia $\left(\mathrm{ER}\left(\mathrm{NH}_{3}\right)_{\mathrm{ijk}}\right)$ and odour $\left(\mathrm{EF}(\text { odour })_{\mathrm{ijk}}\right)$ are calculated per farm location $(i=1,2)$ and measurement period $(j=1,2, \ldots, 6)$ as:

$$
E R\left(N H_{3}\right)_{i j k}=100 \times\left(1-\frac{E\left(N H_{3}\right)_{i j k}}{E\left(N_{3}\right)_{i j 1}}\right) \quad E R(\text { odour })_{i j k}=100 \times\left(1-\frac{E(\text { odour })_{i j k}}{E(\text { odour })_{i j 1}}\right)
$$

2. Then, the calculated emission reductions per treatment and farm location are averaged for all measurement periods to obtain an emission reduction per treatment and farm location.

3. Finally, the calculated emission reductions for both farm locations are averaged to obtain an average emission reduction per treatment.

\subsubsection{Statistical analysis}

The statistical paired difference one-side t-test was used to determine the probability of differences between absolute emissions between treatments to be significant. All analyses were done using the GenStat software (VSN International Ltd, $17^{\text {th }}$ edition). Probability values $\mathrm{P}<0.05$ were considered statistically significant. Values between 0.05 and $0.10(0.05<P<0.10)$ were considered to have a weak significance level, and values $\mathrm{P}>0.10$ were considered to be not significant. 


\section{Results and discussion}

\subsection{Technical results and agronomic requirements}

Table 3 (farm location 1) and Table 4 (farm location 2) show the production results of the two production cycles where five of the six measurements (per farm location) took place. At both farm locations, the last measurement took place at the beginning of a new production cycle, and the production results were not available at the time this report was written. To place these results in a national perspective, Table 3 and Table 4 also show the average production results, as reported in the Quantitative Livestock Information (KWIN, 2014).

At farm location 1, animal loss at the end of the production cycle was lower in the second production cycle (on average $2 \%$ for the four measured rooms) than in the first production cycle (on average $4 \%$ for the four measured rooms). During the first production cycle, animal loss was slightly higher than the agronomic requirements for the rooms provided with the "Traditional" and the "Groene vlag without valves" floors. However, occupation rate during the measurements (Table 6) was always within $5 \%$ of the number of animal places (with the only exception of measurement 2 for the floor "Groene vlag without valves". The average weight of placed and delivered animals were similar in all rooms and between production cycles, and a bit higher than the agronomic requirements. Forage provided to the animals had on average over the whole production cycle more than 250 grams of feed rich in fibre, as required in the Directive 91/629/EEG for veal calves older than eight weeks. The average feed conversion (milk consumption related to growth rate) was 1.5 , and similar between rooms and production cycles.

At farm location 2, animal loss was lower in the second production cycle (on average 3\% for the four measured rooms) than in the first production cycle (on average $8 \%$ for the four measured rooms). Occupation rate during the measurements (Table 7) was always within $5 \%$ of the number of animal places. The average weight of placed and delivered animals were similar in all rooms and between production cycles. The average weight of delivered animals was higher than the agronomic requirements, but also the duration of the production cycle was higher. Forage provided to the animals had on average over the whole production cycle more than 250 grams of feed rich in fibre, as required in the Directive 91/629/EEG for veal calves older than eight weeks. The average feed conversion (milk consumption related to growth rate) was 1.5 , and similar between rooms and production cycles. 
Table 3 Production results for two production cycles at farm location 1, national averages (KWIN, 2014), and agronomic requirements.

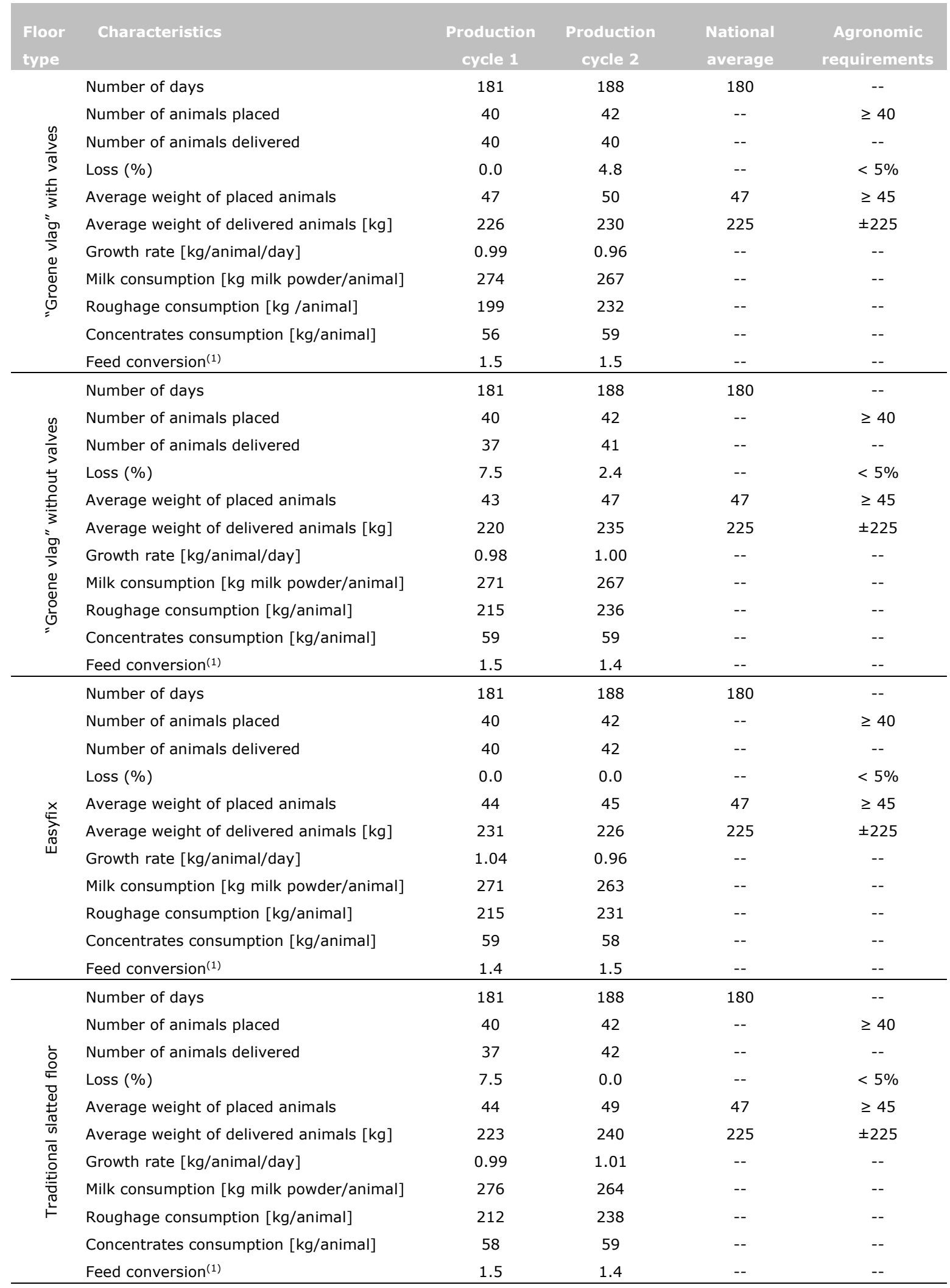

(1) Calculated as milk consumption divided by growth rate 

2014), and agronomic requirements.

\begin{tabular}{|c|c|c|c|c|c|}
\hline $\begin{array}{l}\text { Floor } \\
\text { type }\end{array}$ & Characteristics & $\begin{array}{c}\text { Production } \\
\text { cycle } 1\end{array}$ & $\begin{array}{c}\text { Production } \\
\text { cycle } 2\end{array}$ & $\begin{array}{l}\text { National } \\
\text { average }\end{array}$ & $\begin{array}{l}\text { Agronomic } \\
\text { requirements }\end{array}$ \\
\hline \multirow{11}{*}{ 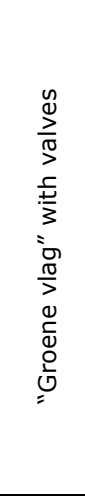 } & Number of days & 204 & 203 & 180 & -- \\
\hline & Number of animals placed & 76 & 76 & -- & $\geq 40$ \\
\hline & Number of animals delivered & 70 & 75 & -- & -- \\
\hline & Loss $(\%)$ & $8.2^{(2)}$ & 1.3 & -- & $<5 \%$ \\
\hline & Average weight of placed animals & 45 & 46 & 47 & $\geq 45$ \\
\hline & Average weight of delivered animals [kg] & 229 & 253 & 225 & \pm 225 \\
\hline & Growth rate $[\mathrm{kg} / \mathrm{animal} / \mathrm{day}]$ & 0.90 & 1.02 & -- & -- \\
\hline & Milk consumption [kg milk powder/animal] & 303 & 274 & -- & -- \\
\hline & Roughage consumption [kg/animal] & 251 & 269 & -- & -- \\
\hline & Concentrates consumption [kg/animal] & --- & --- & -- & -- \\
\hline & Feed conversion $^{(1)}$ & 1.6 & 1.3 & -- & -- \\
\hline \multirow{11}{*}{ 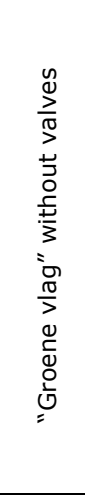 } & Number of days & 204 & 204 & 180 & -- \\
\hline & Number of animals placed & 76 & 74 & -- & $\geq 40$ \\
\hline & Number of animals delivered & 70 & 71 & -- & -- \\
\hline & Loss $(\%)$ & $8.2^{(2)}$ & 4.1 & -- & $<5 \%$ \\
\hline & Average weight of placed animals & 45 & 41 & 47 & $\geq 45$ \\
\hline & Average weight of delivered animals [kg] & 234 & 247 & 225 & \pm 225 \\
\hline & Growth rate $[\mathrm{kg} / \mathrm{animal} / \mathrm{day}]$ & 0.93 & 1.01 & -- & -- \\
\hline & Milk consumption [kg milk powder/animal] & 303 & 277 & -- & -- \\
\hline & Roughage consumption [kg/animal] & 251 & 272 & -- & -- \\
\hline & Concentrates consumption [kg/animal] & --- & --- & -- & -- \\
\hline & Feed conversion $^{(1)}$ & 1.6 & 1.3 & -- & -- \\
\hline \multirow{11}{*}{$\underset{\substack{n \\
\tilde{D}}}{\stackrel{x}{c}}$} & Number of days & 204 & 202 & 180 & -- \\
\hline & Number of animals placed & 76 & 76 & -- & $\geq 40$ \\
\hline & Number of animals delivered & 70 & 72 & -- & -- \\
\hline & Loss $(\%)$ & $8.2^{(2)}$ & 5.3 & -- & $<5 \%$ \\
\hline & Average weight of placed animals & 45 & 41 & 47 & $\geq 45$ \\
\hline & Average weight of delivered animals [kg] & 241 & 227 & 225 & \pm 225 \\
\hline & Growth rate $[\mathrm{kg} / \mathrm{animal} / \mathrm{day}]$ & 0.96 & 0.92 & -- & -- \\
\hline & Milk consumption [kg milk powder/animal] & 303 & 271 & -- & -- \\
\hline & Roughage consumption [kg/animal] & 251 & 263 & -- & -- \\
\hline & Concentrates consumption [kg/animal] & --- & --- & -- & -- \\
\hline & Feed conversion $^{(1)}$ & 1.5 & 1.5 & -- & -- \\
\hline \multirow{11}{*}{ 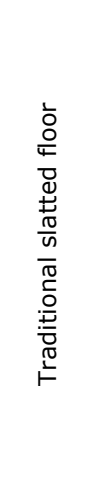 } & Number of days & 204 & 203 & 180 & -- \\
\hline & Number of animals placed & 76 & 76 & -- & $\geq 40$ \\
\hline & Number of animals delivered & 70 & 74 & -- & -- \\
\hline & Loss (\%) & $8.2^{(2)}$ & 2.6 & -- & $<5 \%$ \\
\hline & Average weight of placed animals & 45 & 41 & 47 & $\geq 45$ \\
\hline & Average weight of delivered animals [kg] & 234 & 243 & 225 & \pm 225 \\
\hline & Growth rate $[\mathrm{kg} / \mathrm{animal} / \mathrm{day}]$ & 0.93 & 0.99 & -- & -- \\
\hline & Milk consumption [kg milk powder/animal] & 303 & 274 & -- & -- \\
\hline & Roughage consumption [kg/animal] & 251 & 269 & -- & -- \\
\hline & Concentrates consumption [kg/animal] & --- & --- & -- & -- \\
\hline & Feed conversion $^{(1)}$ & 1.6 & 1.4 & -- & -- \\
\hline
\end{tabular}

(1) Calculated as milk consumption divided by growth rate

(2) Average loss for all rooms, individual loss not known 


\subsection{Cleanliness of floor and animals}

Table 5 shows the degree of cleanliness of the floor and animals (visually inspected and rated) during the measurements, for both farm locations and all floor types. In general, animals were considered to be clean to reasonable clean at both locations, for all floor types. Regarding the cleanliness of the floors, large differences were observed. The "Groene vlag" floors (with and without valves) scored generally as "reasonable clean", while both the traditional wooden slatted floor and Easyfix scored generally as "dirty". During the inspections performed during the first production cycle at both farm locations it was found that the valves were not working properly. At farm location 1, the slots with valves were in some cases filled with manure. At farm location 2, some of the valves were gone due to improper mounting, and had to be replaced.

Table 5 Cleanliness of floor and animals as observed during the measurements.

\begin{tabular}{|c|c|c|c|c|c|}
\hline \multirow[t]{2}{*}{ Measurement } & \multirow[t]{2}{*}{ Floor type } & \multicolumn{2}{|c|}{ Cleanliness farm location 1} & \multicolumn{2}{|c|}{ Cleanliness farm location 2} \\
\hline & & Floor & Animals & Floor & Animals \\
\hline \multirow{4}{*}{1} & "Groene vlag" with valves & 2 & $1-2$ & 2 & $1-2$ \\
\hline & "Groene vlag" without valves & 3 & $1-2$ & 2 & $1-2$ \\
\hline & Easyfix & 4 & $1-2$ & 4 & $1-2$ \\
\hline & Traditional wooden slats & 4 & $1-2$ & 4 & $1-2$ \\
\hline \multirow{4}{*}{2} & "Groene vlag" with valves & 2 & $1-2$ & 2 & $1-2$ \\
\hline & "Groene vlag" without valves & 2 & $1-2$ & 2 & $1-2$ \\
\hline & Easyfix & 4 & $1-2$ & 4 & $1-2$ \\
\hline & Traditional wooden slats & 4 & $1-2$ & 4 & $1-2$ \\
\hline \multirow{4}{*}{3} & "Groene vlag" with valves & 1 & $1-2$ & 2 & $1-2$ \\
\hline & "Groene vlag" without valves & 2 & $1-2$ & 2 & $1-2$ \\
\hline & Easyfix & 4 & $1-2$ & 4 & $1-2$ \\
\hline & Traditional wooden slats & 3 & $1-2$ & 4 & $1-2$ \\
\hline \multirow{4}{*}{4} & "Groene vlag" with valves & 2 & $1-2$ & 2 & $1-2$ \\
\hline & "Groene vlag" without valves & 2 & $1-2$ & 2 & $1-2$ \\
\hline & Easyfix & 4 & $1-2$ & 4 & $1-2$ \\
\hline & Traditional wooden slats & 4 & $1-2$ & 4 & $1-2$ \\
\hline \multirow{4}{*}{5} & "Groene vlag" with valves & 2 & $1-2$ & 2 & $1-2$ \\
\hline & "Groene vlag" without valves & 2 & $1-2$ & 2 & $1-2$ \\
\hline & Easyfix & 4 & $1-2$ & 3 & $1-2$ \\
\hline & Traditional wooden slats & 4 & $1-2$ & 4 & $1-2$ \\
\hline \multirow{4}{*}{6} & "Groene vlag" with valves & 2 & $1-2$ & 2 & $1-2$ \\
\hline & "Groene vlag" without valves & 2 & $1-2$ & 2 & $1-2$ \\
\hline & Easyfix & 4 & $1-2$ & 4 & $1-2$ \\
\hline & Traditional wooden slats & 4 & $1-2$ & 4 & $1-2$ \\
\hline
\end{tabular}

\subsection{Measurement conditions}

Table 6 (farm location 1) and Table 7 (farm location 2) give an overview of the measurement conditions during the measurements. The measurements were performed within a period of 250 days (farm location 1) and 294 days (farm location 2) distributed over the year (Figure 7a) and the production cycle (Figure $7 \mathrm{~b}$ ) according to the requisites of the measurement protocol (half of the measurements on the first half of the production cycle, half of the measurements on the second half of the production cycle and distributed over three different seasons). Considering all six measurements, the average measurement day in the year was 161 days for farm location 1, and 155 for farm location 2. The average day in the production cycle was 95 days for farm location 1 , and 100 for farm location 2. The degree of occupation (number of animals in the rooms compared to the number of animal places based on $1.8 \mathrm{~m}^{2} /$ animal) varied between $93 \%$ and $105 \%$ (average $101 \%$ ) for farm location 1, and between $95 \%$ and $100 \%$ (average $99 \%$ ) for farm location 2. The concentration of carbon dioxide $\left(\mathrm{CO}_{2}\right)$ in the rooms was always below $3000 \mathrm{ppm}$. As pointed out in section 3.1, animals were provided with roughage having (on average over the whole production cycle) at least 250 grams of 
feed rich in fibre. Animals were provided with standard veterinary care (see Appendix 2 for an overview of the animals being treated for the production cycles were measurements took place).

Table 6 Measurement conditions for the measurements performed at farm location 1.

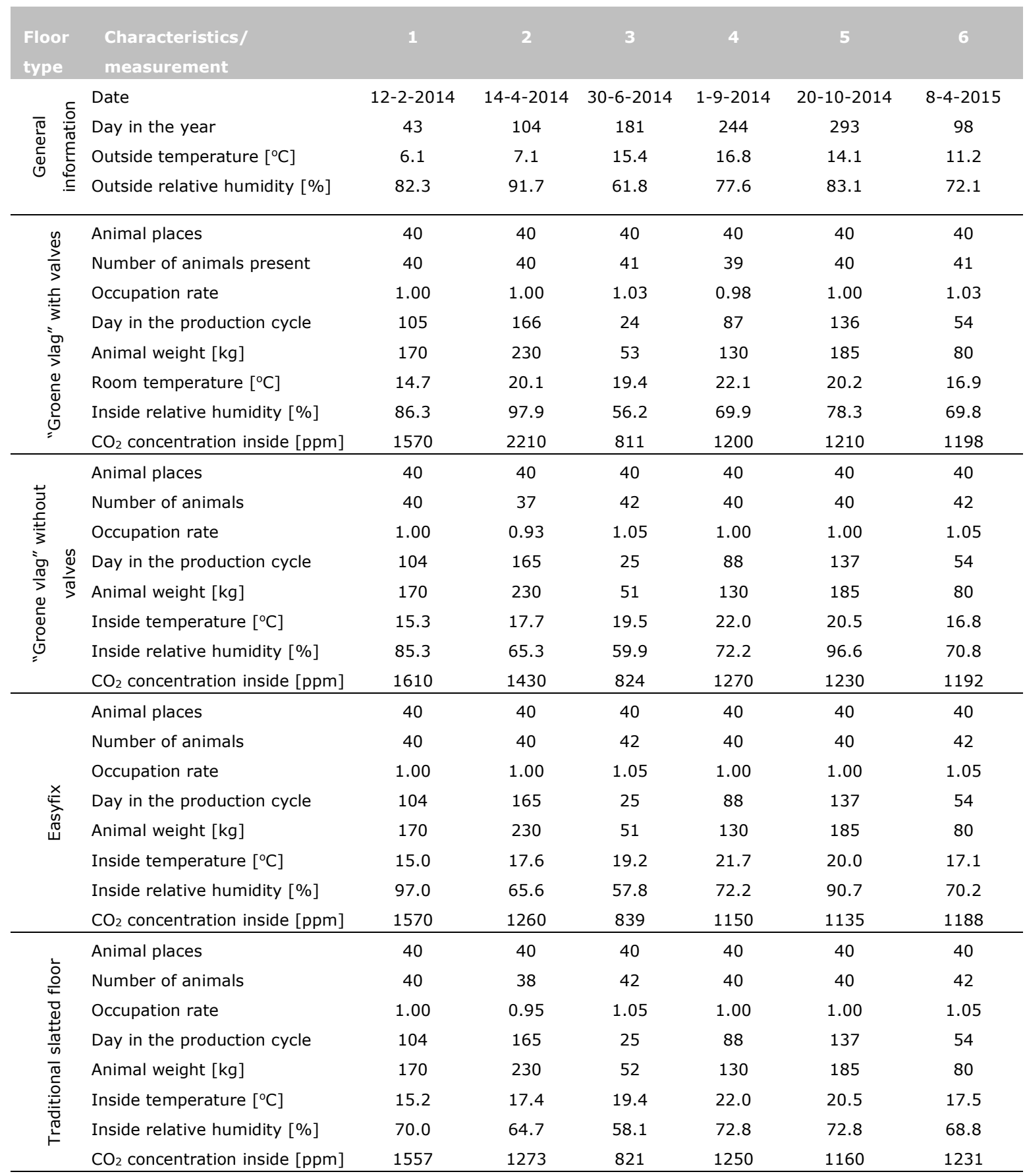




\begin{tabular}{|c|c|c|c|c|c|c|c|}
\hline $\begin{array}{l}\text { Floor } \\
\text { type }\end{array}$ & $\begin{array}{l}\text { Characteristics/ } \\
\text { measurement }\end{array}$ & 1 & 2 & 3 & 4 & 5 & 6 \\
\hline \multirow{4}{*}{ 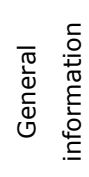 } & Date & $27-3-2014$ & $2-6-2014$ & $15-9-2014$ & $27-10-2014$ & $6-1-2015$ & $6-5-2015$ \\
\hline & Day in the year & 86 & 153 & 258 & 300 & 6 & 126 \\
\hline & Outside temperature $\left[{ }^{\circ} \mathrm{C}\right]$ & 11.4 & 18.6 & 19.3 & 12.6 & 3.4 & 13.3 \\
\hline & Outside relative humidity [\%] & 53.3 & 56.8 & 83.0 & 84.4 & 89.9 & 70.6 \\
\hline \multirow{8}{*}{ 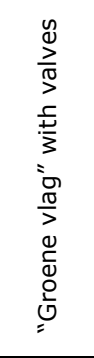 } & Animal places & 76 & 76 & 76 & 76 & 76 & 76 \\
\hline & Number of animals & 76 & 76 & 75 & 76 & 76 & 76 \\
\hline & Occupation rate & 1.00 & 1.00 & 0.99 & 1.00 & 1.00 & 1.00 \\
\hline & Day in the production cycle & 107 & 174 & 40 & 82 & 153 & 44 \\
\hline & Animal weight $[\mathrm{kg}]$ & 160 & 220 & 76 & 118 & 215 & 60 \\
\hline & Inside temperature $\left[{ }^{\circ} \mathrm{C}\right]$ & 17.7 & 33.5 & 22.8 & 19.9 & 16.1 & 19.0 \\
\hline & Inside relative humidity [\%] & 62.2 & 46.5 & 72.9 & 77.6 & 84.2 & 63.2 \\
\hline & $\mathrm{CO}_{2}$ concentration inside $[\mathrm{ppm}]$ & 920 & 956 & 911 & 1063 & 1910 & 1165 \\
\hline \multirow{8}{*}{ 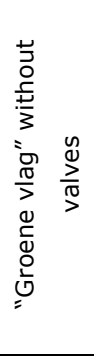 } & Animal places & 76 & 76 & 76 & 76 & 76 & 76 \\
\hline & Number of animals & 76 & 74 & 74 & 72 & 72 & 76 \\
\hline & Occupation rate & 1.00 & 0.97 & 0.97 & 0.95 & 0.95 & 1.00 \\
\hline & Day in the production cycle & 107 & 174 & 40 & 82 & 153 & 42 \\
\hline & Animal weight $[\mathrm{kg}]$ & 160 & 220 & 74 & 116 & 213 & 60 \\
\hline & Inside temperature $\left[{ }^{\circ} \mathrm{C}\right]$ & 17.3 & 23.0 & 22.6 & 19.6 & 16.1 & 19.2 \\
\hline & Inside relative humidity [\%] & 61.2 & 59.3 & 75.7 & 75.4 & 82.0 & 62.7 \\
\hline & $\mathrm{CO}_{2}$ concentration inside $[\mathrm{ppm}]$ & 838 & 1150 & 960 & 1280 & n.a. & 1232 \\
\hline \multirow{8}{*}{ 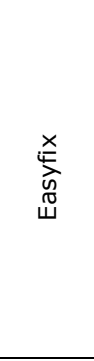 } & Animal places & 76 & 76 & 76 & 76 & 76 & 76 \\
\hline & Number of animals & 76 & 76 & 76 & 76 & 74 & 75 \\
\hline & Occupation rate & 1.00 & 1.00 & 1.00 & 1.00 & 0.97 & 0.99 \\
\hline & Day in the production cycle & 107 & 174 & 40 & 82 & 153 & 41 \\
\hline & Animal weight $[\mathrm{kg}]$ & 165 & 220 & 70 & 112 & 208 & 56 \\
\hline & Inside temperature $\left[{ }^{\circ} \mathrm{C}\right]$ & 17.7 & 23.3 & 22.9 & 20.2 & 15.9 & 19.4 \\
\hline & Inside relative humidity [\%] & 65.7 & 58.5 & 73.2 & 76.6 & 81.9 & 65.9 \\
\hline & $\mathrm{CO}_{2}$ concentration inside $[\mathrm{ppm}]$ & 1170 & 996 & 975 & 1470 & n.a. & 1276 \\
\hline \multirow{8}{*}{ 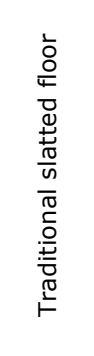 } & Animal places & 76 & 76 & 76 & 76 & 76 & 76 \\
\hline & Number of animals & 76 & 76 & 76 & 75 & 75 & 76 \\
\hline & Occupation rate & 1.00 & 1.00 & 1.00 & 0.99 & 0.99 & 1.00 \\
\hline & Day in the production cycle & 107 & 174 & 40 & 82 & 153 & 41 \\
\hline & Animal weight $[\mathrm{kg}]$ & 162 & 220 & 73 & 117 & 210 & 60 \\
\hline & Inside temperature $\left[{ }^{\circ} \mathrm{C}\right]$ & 17.5 & 23.7 & 23.0 & 19.6 & 16.3 & 18.7 \\
\hline & Inside relative humidity [\%] & 64.1 & 59.1 & 73.2 & 98.1 & 84.0 & 62.8 \\
\hline & $\mathrm{CO}_{2}$ concentration inside $[\mathrm{ppm}]$ & 1020 & 1160 & 980 & 1490 & n.a. & 1083 \\
\hline
\end{tabular}
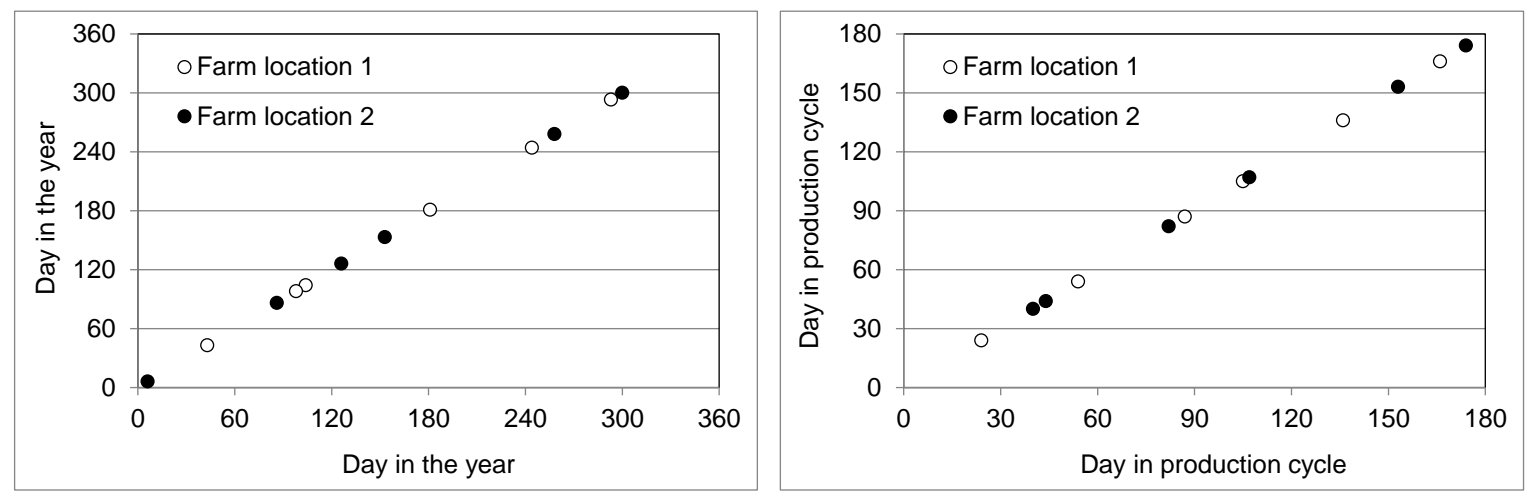

Figure 7 Distribution of measurements $A$ ) in the year and B) in the production cycle for both farm locations. 
Figure 8 shows the average outside temperature at the days were measurements were performed, for both farm locations and compared to the average outside temperature as measured in the weather station De Bilt (in the middle of the Netherlands) during the last 10 years (period 2004-2013). The average outside temperature during the measurements was $11.8^{\circ} \mathrm{C}$ for farm location 1 and $13.1^{\circ} \mathrm{C}$ for farm location 2. Outside temperature was for both farm locations higher than the average of the last 10 years $\left(10.5^{\circ} \mathrm{C}\right)$.
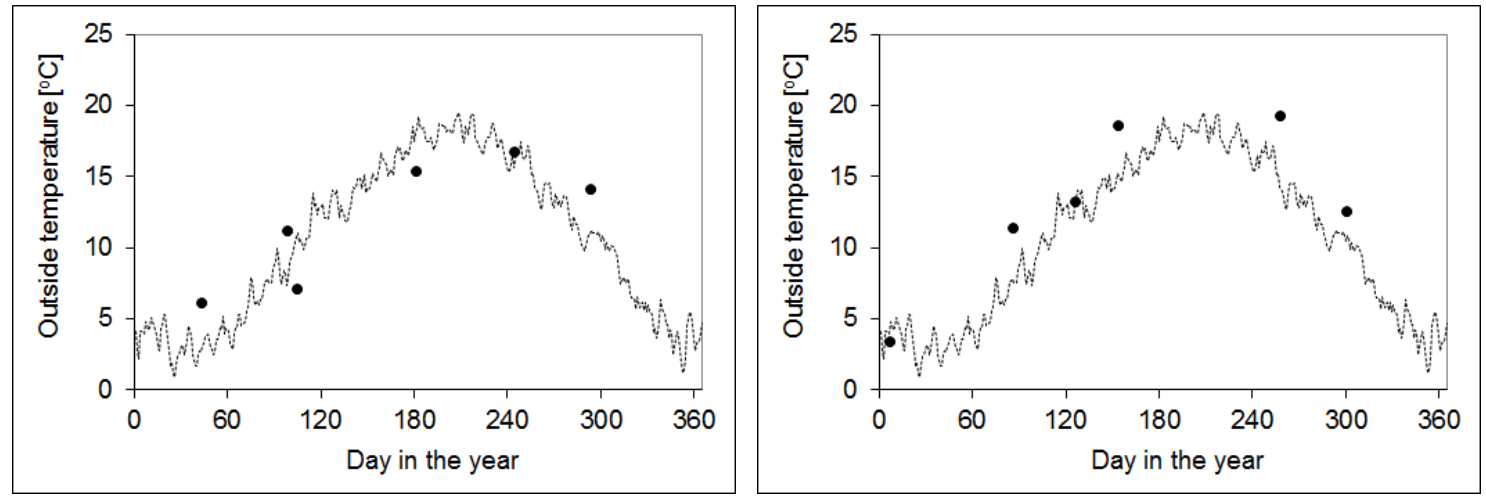

Figure 8 Outside temperature measured at farm location 1 (left side) and farm location 2 (right side), compared to the average (2004-2013) outside temperature measured in the Netherlands at the weather station De Bilt (www.knmi.nl; shown as dotted line).

Figure 9 shows the ventilation rate $\left(\mathrm{m}^{3} / \mathrm{h}\right.$ per animal) measured at both farm locations for all investigated rooms/floors. At farm location 1 , the ventilation rate showed some variation between rooms but was for all rooms and measurements similar, except for measurement 2 at room 1 . Due to a failure in the computer system regulating the ventilation from this room, the ventilation rate was part of the measurement day at a low level, much lower than by the other rooms. At farm location 2, ventilation rate was similar for all rooms during all measurement periods.

A)
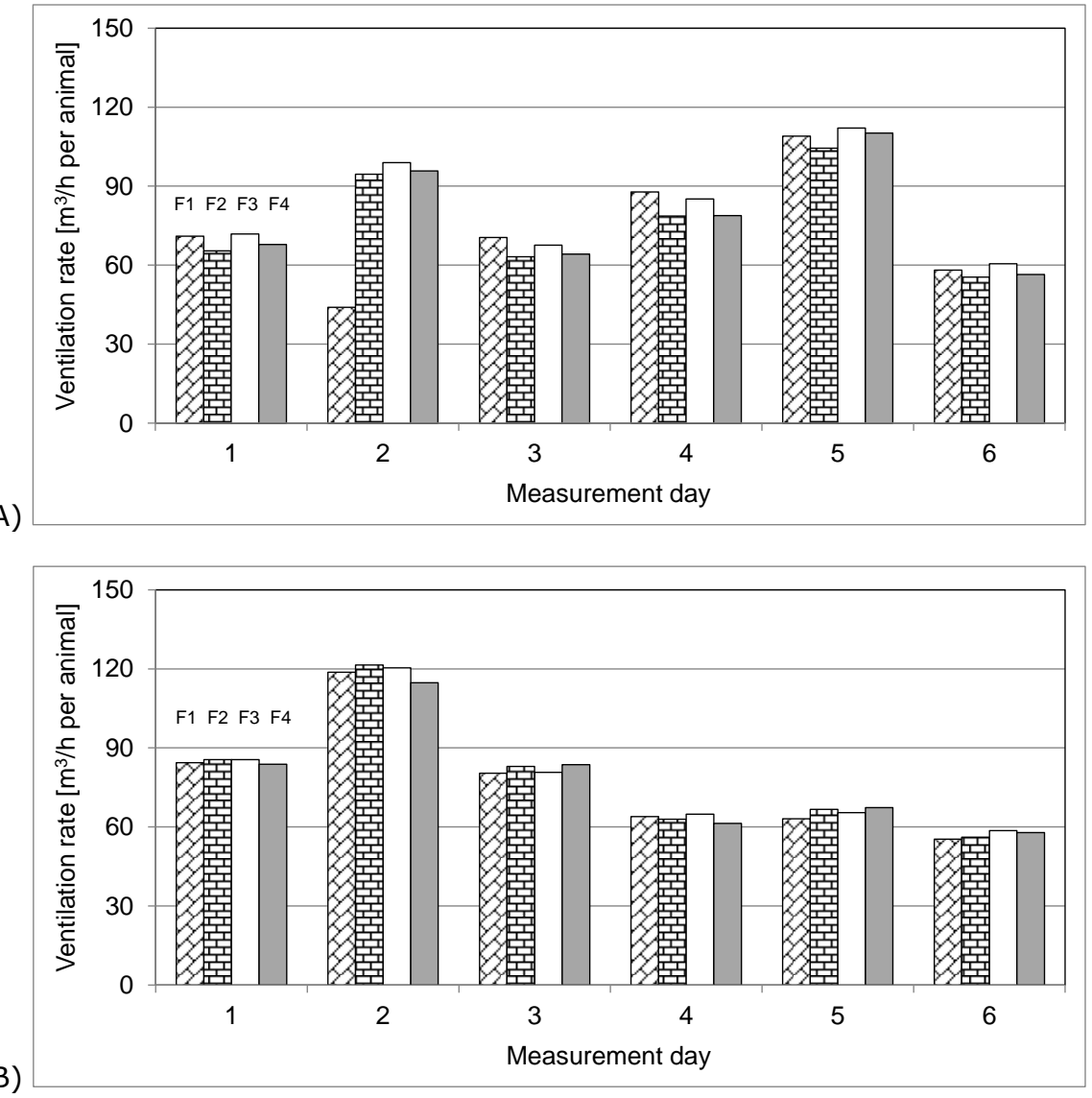

Figure 9 Ventilation rate $\left(\mathrm{m}^{3} / \mathrm{h}\right.$ per animal) for both farm location (A: farm location 1; B: farm location 2) and rooms (F1: "Groene vlag" with valves; F2: "Groene vlag" without valves; F3: EasyFix; F4: traditional wooden slatted floor). 


\subsection{Ammonia and odour emissions}

Table 8 (farm location 1 ) and Table 9 (farm location 2) give an overview of the available data regarding the emission of ammonia and odour during all measurement periods.

Table 8 Results of measurements performed at farm location 1. Emissions are corrected for the percentage of the days the rooms were occupied (93\% for white veal calves; Groenestein and Aarnink, 2008).

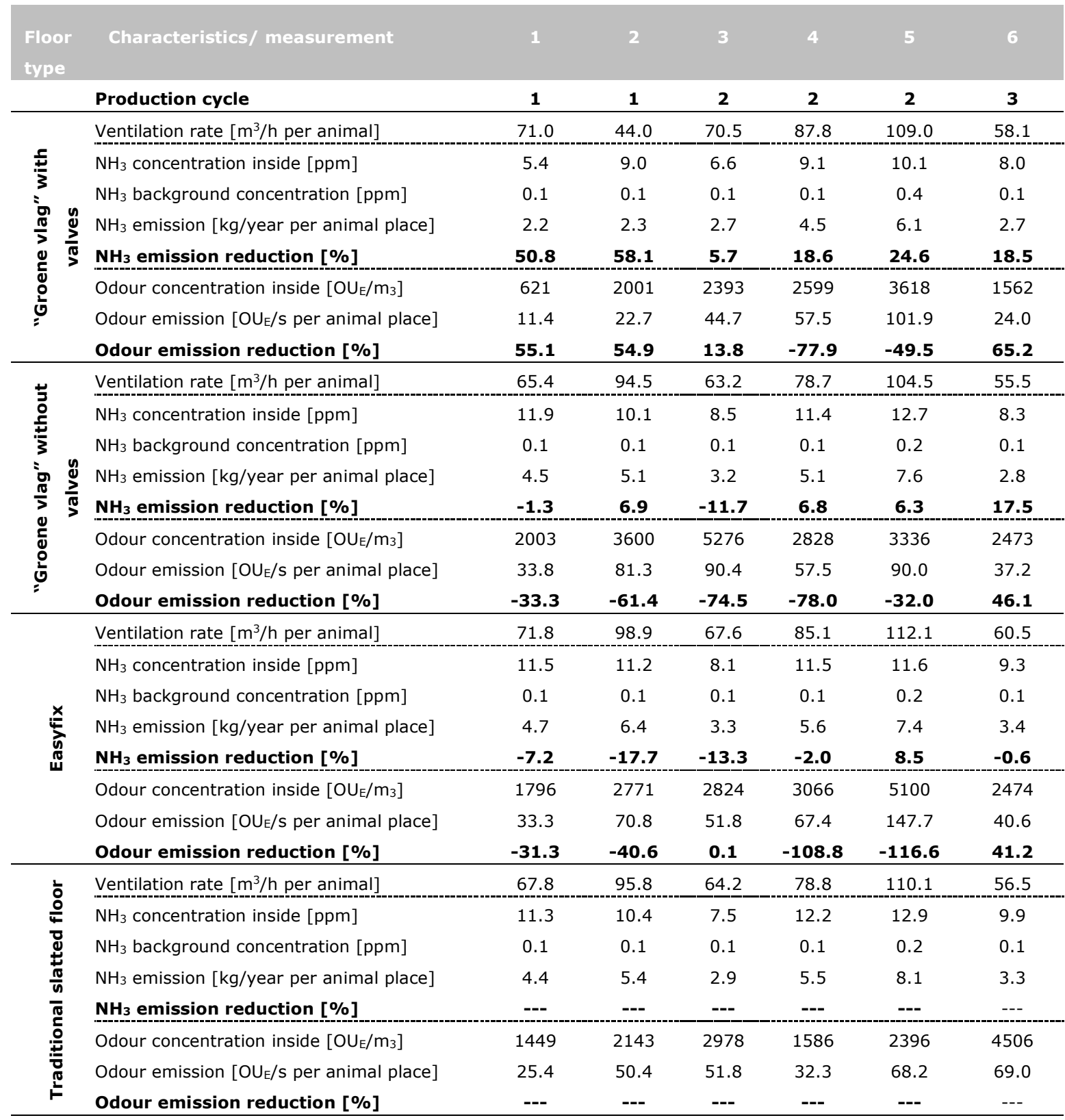


Results of measurements performed at farm location 2. Emissions are corrected for the percentage of the days the rooms were occupied (93\% for white veal calves; Groenestein and Aarnink, 2008).

\begin{tabular}{|c|c|c|c|c|c|c|c|}
\hline \multirow{2}{*}{$\begin{array}{l}\text { Floor } \\
\text { type }\end{array}$} & Characteristics/ measurement & 1 & 2 & 3 & 4 & 5 & 6 \\
\hline & Production cycle & 1 & 1 & 2 & 2 & 2 & 3 \\
\hline \multirow{8}{*}{ 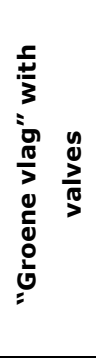 } & Ventilation rate $\left[\mathrm{m}^{3} / \mathrm{h}\right.$ per animal $]$ & 84.4 & 118.8 & 80.4 & 63.9 & 63.1 & 55.3 \\
\hline & $\mathrm{NH}_{3}$ concentration inside $[\mathrm{ppm}]$ & 6.6 & 8.4 & 7.0 & 12.0 & 15.7 & 12.5 \\
\hline & $\mathrm{NH}_{3}$ background concentration [ppm] & 0.1 & 0.1 & 0.1 & 0.1 & 0.3 & 0.3 \\
\hline & $\mathrm{NH}_{3}$ emission $[\mathrm{kg} /$ year per animal place $]$ & 3.2 & 5.7 & 3.1 & 4.4 & 5.6 & 3.9 \\
\hline & $\mathrm{NH}_{3}$ emission reduction [\%] & 21.8 & 1.0 & 43.7 & 14.1 & 1.1 & 9.9 \\
\hline & Odour concentration inside $\left[\mathrm{OU}_{\mathrm{E}} / \mathrm{m}_{3}\right]$ & 1269 & 2144 & 1237 & 1924 & 1872 & 3299 \\
\hline & Odour emission $\left[\mathrm{OU}_{\mathrm{E}} / \mathrm{s}\right.$ per animal place] & 27.7 & 65.8 & 25.4 & 31.8 & 30.5 & 47.2 \\
\hline & Odour emission reduction [\%] & 47.4 & -28.5 & -76.5 & 0.0 & 19.5 & -12.3 \\
\hline \multirow{8}{*}{ 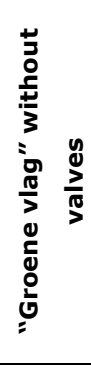 } & Ventilation rate $\left[\mathrm{m}^{3} / \mathrm{h}\right.$ per animal] & 85.6 & 121.4 & 83.0 & 63.0 & 66.7 & 56.2 \\
\hline & $\mathrm{NH}_{3}$ concentration inside $[\mathrm{ppm}]$ & 6.9 & 7.5 & 10.5 & 14.2 & 16.4 & 13.9 \\
\hline & $\mathrm{NH}_{3}$ background concentration [ppm] & 0.1 & 0.1 & 0.1 & 0.1 & 0.1 & 0.3 \\
\hline & $\mathrm{NH}_{3}$ emission $[\mathrm{kg} /$ year per animal place $]$ & 3.4 & 5.1 & 4.8 & 4.9 & 5.9 & 4.4 \\
\hline & $\mathrm{NH}_{3}$ emission reduction [\%] & 17.1 & 12.0 & 13.5 & 4.9 & -4.1 & -2.3 \\
\hline & Odour concentration inside $\left[\mathrm{OU}_{E} / \mathrm{m}_{3}\right]$ & 1756 & 1116 & 629 & 1667 & 3326 & 3474 \\
\hline & Odour emission $\left[O U_{E} / s\right.$ per animal place $]$ & 38.8 & 34.1 & 13.1 & 25.7 & 54.3 & 50.4 \\
\hline & Odour emission reduction [\%] & 26.2 & 33.4 & 8.6 & 19.1 & -43.1 & -20.0 \\
\hline \multirow{8}{*}{ 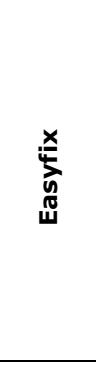 } & Ventilation rate $\left[\mathrm{m}^{3} / \mathrm{h}\right.$ per animal] & 85.6 & 120.4 & 80.8 & 64.9 & 65.4 & 58.6 \\
\hline & $\mathrm{NH}_{3}$ concentration inside $[\mathrm{ppm}]$ & 9.0 & 8.6 & 10.1 & 16.2 & 16.4 & 13.5 \\
\hline & $\mathrm{NH}_{3}$ background concentration [ppm] & 0.1 & 0.1 & 0.1 & 0.1 & 0.3 & 0.3 \\
\hline & $\mathrm{NH}_{3}$ emission $[\mathrm{kg} /$ year per animal place] & 4.4 & 5.9 & 4.7 & 6.0 & 5.9 & 4.4 \\
\hline & $\mathrm{NH}_{3}$ emission reduction [\%] & -8.0 & -2.3 & 16.6 & -18.2 & -3.8 & -2.3 \\
\hline & Odour concentration inside $\left[\mathrm{OU}_{E} / \mathrm{m}_{3}\right]$ & 2281 & 1727 & 881 & 2824 & 3076 & 1295 \\
\hline & Odour emission $\left[O U_{E} / s\right.$ per animal place] & 50.4 & 53.7 & 18.4 & 47.3 & 50.6 & 19.4 \\
\hline & Odour emission reduction [\%] & 4.2 & -4.9 & -27.9 & -49.0 & -33.4 & 53.9 \\
\hline \multirow{8}{*}{ 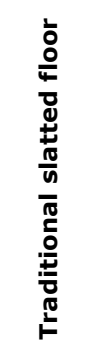 } & Ventilation rate $\left[\mathrm{m}^{3} / \mathrm{h}\right.$ per animal] & 83.8 & 114.7 & 83.6 & 61.4 & 67.4 & 57.8 \\
\hline & $\mathrm{NH}_{3}$ concentration inside $[\mathrm{ppm}]$ & 8.5 & 8.8 & 11.7 & 14.7 & 15.0 & 13.1 \\
\hline & $\mathrm{NH}_{3}$ background concentration [ppm] & 0.1 & 0.1 & 0.1 & 0.1 & 0.1 & 0.2 \\
\hline & $\mathrm{NH}_{3}$ emission $[\mathrm{kg} /$ year per animal place] & 4.0 & 5.8 & 5.6 & 5.1 & 5.7 & 4.3 \\
\hline & $\mathrm{NH}_{3}$ emission reduction [\%] & --- & --- & --- & --- & --- & --- \\
\hline & Odour concentration inside $\left[\mathrm{OU}_{\mathrm{E}} / \mathrm{m}_{3}\right]$ & 2431 & 1727 & 665 & 2030 & 2209 & 2811 \\
\hline & Odour emission $\left[\mathrm{OU}_{E} / \mathrm{s}\right.$ per animal place] & 52.6 & 51.2 & 14.4 & 31.8 & 37.9 & 42.0 \\
\hline & Odour emission reduction [\%] & --- & --- & --- & --- & --- & --- \\
\hline
\end{tabular}

Based on all available data, the following ammonia emissions were determined:

\begin{tabular}{|c|c|c|c|}
\hline \multirow[t]{2}{*}{ Floor } & \multicolumn{3}{|c|}{ Ammonia emission [kg/year per animal place] } \\
\hline & $\begin{array}{c}\text { Farm } \\
\text { location } 1\end{array}$ & Farm location 2 & Both farms $(n=2)$ \\
\hline "Groene vlag" with valves & 3.4 & 4.3 & 3.9 \\
\hline "Groene vlag" without valves & 4.7 & 4.7 & 4.7 \\
\hline EasyFix & 5.1 & 5.2 & 5.2 \\
\hline $\begin{array}{l}\text { Traditional wooden slatted } \\
\text { floor }\end{array}$ & 4.9 & 5.1 & 5.0 \\
\hline
\end{tabular}

Ammonia emissions were similar between farm locations. The measured farm emissions from the traditional wooden slatted floor (on average $5.0 \mathrm{~kg} / \mathrm{year}$ per animal place, corrected for the percentage of the days the rooms were occupied (93\% for white veal calves; Groenestein and Aarnink, 2008)) were higher than the emission factor (3.5 kg/year per animal place) provided in the Regulation Ammonia and Livestock (Rav, Regeling ammoniak en veehouderij; Staatscourant, 2015). These emissions are also higher than the emissions reported in Hol and Groenestein (1997) and 
Beurskens and Hol (2004): $2.5 \mathrm{~kg} /$ year per animal place and $3.4 \mathrm{~kg} / \mathrm{year}$ per animal place, respectively.

Based on all available data, the following ammonia emission reductions (emission of the floor compared to the emission from the traditional wooden slatted floor as simultaneously measured at the same farm location) were determined:

\begin{tabular}{|c|c|c|c|}
\hline \multirow[t]{3}{*}{ Floor } & \multicolumn{3}{|c|}{$\begin{array}{c}\text { Ammonia emission reduction [ } \% \text { of traditional wooden slatted } \\
\text { floor] } \\
\text { average } \pm \text { standard error of the means }\end{array}$} \\
\hline & \multicolumn{2}{|c|}{ Individual farms $(n=6)$} & \multirow{2}{*}{ Both farms $(n=12)$} \\
\hline & $\begin{array}{c}\text { Farm } \\
\text { location } 1\end{array}$ & Farm location 2 & \\
\hline "Groene vlag" with valves & $29.4 \pm 8.4$ & $15.3 \pm 6.5$ & $22.3 \pm 5.5$ \\
\hline "Groene vlag" without valves & $4.1 \pm 4.0$ & $6.9 \pm 3.6$ & $5.5 \pm 2.6$ \\
\hline EasyFix & $-5.4 \pm 3.9$ & $-3.0 \pm 4.6$ & $-4.2 \pm 2.9$ \\
\hline
\end{tabular}

Ammonia emissions from the floor "Groene vlag" with valves were significantly lower (22.3\% lower; Pvalue: 0.03 ) when compared to the emission from the traditional floor measured simultaneously within the same farm (case-control approach; Figure 10a). Emission reductions were higher at the end of the production cycle at farm location 1 , but lower at farm location 2 . This could be related with the problems encountered at farm location 2 with the valves used for this floor (see section 3.2).

Ammonia emissions from the floor "Groene vlag" without valves were 5.5\% lower but differences were not significant ( $\mathrm{P}$-value: $>0.10$ ) when compared to the emission from the traditional floor measured simultaneously within the same farm (case-control approach; Figure 10b).

Ammonia emissions from the floor "EasyFix" were $4.2 \%$ higher but differences were not significant ( $P$ value: $>0.10$ ) when compared to the emission from the traditional floor measured simultaneously within the same farm (case-control approach; Figure 10c).
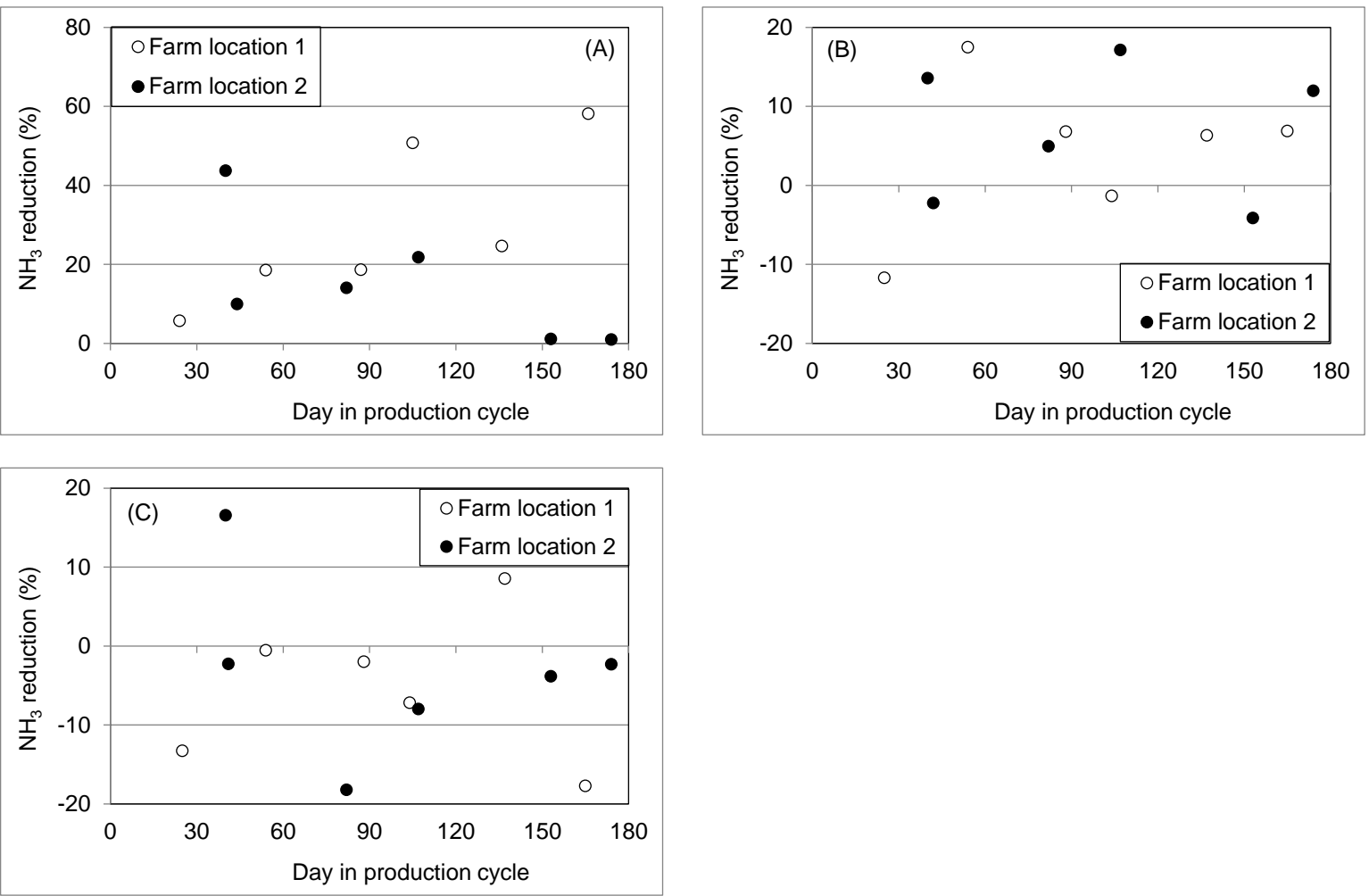

Figure 10 Ammonia emission reduction (compared to the traditional wooden slatted floor) for both farm locations and rooms (A: "Groene vlag" with valves; B: "Groene vlag" without valves; C: EasyFix). 
Based on all available data, the following odour emissions were determined:

\begin{tabular}{|c|c|c|c|}
\hline \multirow[t]{2}{*}{ Floor } & \multicolumn{3}{|c|}{ Odour emission $\left[\mathrm{OU}_{\mathrm{E}} / \mathrm{s}\right.$ per animal place] } \\
\hline & $\begin{array}{c}\text { Farm } \\
\text { location } 1\end{array}$ & Farm location 2 & Both farms $(n=2)$ \\
\hline "Groene vlag" with valves & 34.3 & 35.8 & 35.1 \\
\hline "Groene vlag" without valves & 60.3 & 32.7 & 46.5 \\
\hline EasyFix & 60.6 & 36.4 & 48.5 \\
\hline Traditional wooden slatted floor & 46.5 & 35.4 & 40.9 \\
\hline
\end{tabular}

Odour emissions from the traditional wooden slatted floor (on average $40.9 \mathrm{OU}_{\mathrm{E}} / \mathrm{s}$ per animal place, corrected for the percentage of the days the rooms were occupied ( $93 \%$ for white veal calves; Groenestein and Aarnink, 2008)) were similar to the assigned emission factor of $35.6 \mathrm{OU}_{\mathrm{E}} / \mathrm{s}$ per animal place (Staatscourant, 2013). These emissions are also similar to the emissions reported in Beurskens and Hol (2004): $41.8 \mathrm{OU}_{\mathrm{E}} / \mathrm{s}$ per animal place.

Based on all available data, the following odour emission reductions (emission of the floor compared to the emission from the traditional wooden slatted floor as simultaneously measured at the same farm location) were determined:

\begin{tabular}{|c|c|c|c|}
\hline \multirow[t]{4}{*}{ Floor } & \multicolumn{3}{|c|}{ Odour emission reduction [\% of traditional wooden slatted floor] } \\
\hline & \multicolumn{3}{|c|}{ average \pm standard error of the means } \\
\hline & Individt & arms $(n=6)$ & Both farms $(n=12)$ \\
\hline & $\begin{array}{c}\text { Farm } \\
\text { location } 1\end{array}$ & Farm location 2 & \\
\hline "Groene vlag" with valves & $26.2 \pm 24.8$ & $-1.2 \pm 17.3$ & $12.5 \pm 14.7$ \\
\hline "Groene vlag" without valves & $-29.7 \pm 18.8$ & $7.6 \pm 12.1$ & $-11.1 \pm 12.5$ \\
\hline EasyFix & $-30.4 \pm 25.1$ & $-2.8 \pm 14.9$ & $-16.6 \pm 14.8$ \\
\hline
\end{tabular}

Odour emissions from the floor "Groene vlag" with valves were $12.5 \%$ lower but differences were not significant ( $P$-value: $>0.10$ ) when compared to the emission from the traditional floor measured simultaneously within the same farm (case-control approach; Figure 11a).

Odour emissions from the floor "Groene vlag" without valves were $11.1 \%$ higher but differences were not significant ( $P$-value: $>0.10$ ) when compared to the emission from the traditional floor measured simultaneously within the same farm (case-control approach; Figure 11b).

Odour emissions from the floor "EasyFix" were $16.6 \%$ higher but differences were not significant ( $\mathrm{P}$ value $>0.10$ ) when compared to the emission from the traditional floor measured simultaneously within the same farm (case-control approach; Figure 11c). 

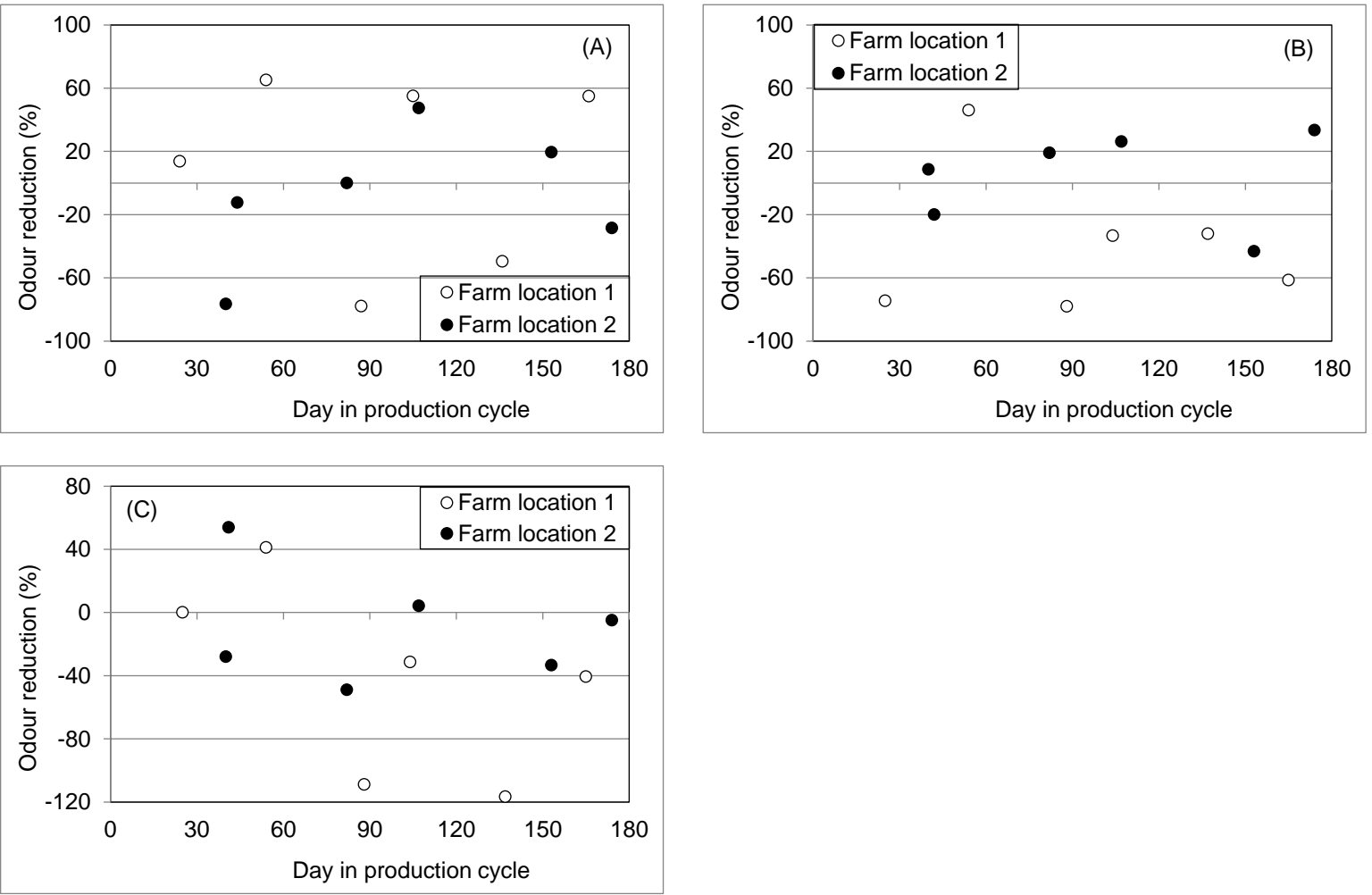

Figure 11 Odour emission reduction (compared to the traditional wooden slatted floor) for both farm locations and rooms (A: "Groene vlag" with valves; B: "Groene vlag" without valves; C: EasyFix). 


\section{Conclusions}

This rapport shows the results of measurements performed at two animal facilities for veal calves using the control-case approach, to determine the emission reduction of a number of floors compared to the traditional wooden slatted floor:

- "Groene Vlag" slatted floor

- $\quad$ "Groene Vlag" slatted floor with sealing valves in de slots

- $\quad$ Easyfix slatted floor

Based on all available data, the following emission reductions (emission of the floor compared to the emission from the traditional wooden slatted floor as simultaneously measured at the same farm location) were determined:

\begin{tabular}{lcc} 
Floor & $\begin{array}{c}\text { average reductiont standard error of the means } \\
\text { Ammonia } \\
(\% \text { reduction) }\end{array}$ & $\begin{array}{c}\text { Odour } \\
\text { (\% reduction) }\end{array}$ \\
\hline "Groene vlag" with valves & $22.3 \pm 5.5$ & $12.5 \pm 14.7$ \\
\hline "Groene vlag" without valves & $5.5 \pm 2.6$ & $-11.1 \pm 12.5$ \\
\hline EasyFix & $-4.2 \pm 2.9$ & $-16.6 \pm 14.8$ \\
\hline
\end{tabular}

Ammonia emissions from the floor "Groene vlag" with valves were significantly lower (22.3\% lower; Pvalue: 0.03$)$, whereas measured means from the floors "Groene vlag" without valves (5.5\% lower) and "EasyFix" (4.2\% higher) were not significantly different (P-value: $>0.10$ ) when compared to the emission from the traditional floor measured simultaneously within the same farm (case-control approach).

Odour emissions from all measured floors ("Groene vlag" with valves, $12.5 \%$ lower ; "Groene vlag" without valves, $11.1 \%$ higher; "EasyFix", $16.6 \%$ higher) were not significantly different (Pvalue $>0.10$ ) when compared to the emission from the traditional floor measured simultaneously within the same farm (case-control approach). 


\section{References}

Beurskens, A.G.C., and J.M.G. Hol. 2004. Onderzoek naar de ammoniak- en geuremissie van stallen LXI. Stal voor vleeskalveren (witvlees productie). A\&F Rapport 220.

CEN standard 13725. 2003. Air quality - determination of odour concentration by dynamic olfactometry, European Committee for Standardization, Brussels, Belgium.

Groenestein, C.M. en A.J.A. Aarnink. 2008. Notitie over leegstand ten behoeve van het berekenen van een emissiefactor van een stal. Intern rapport 200808, Animal Science Group van Wageningen UR, Lelystad, The Netherlands.

Hol, J.M.G., and C.M. Groenestein. 1997. Praktijkonderzoek naar de ammoniakemissie van stallen XXXI. Verschillende huisvestingssystemen voor vleeskalveren. DLO Rapport 97-1001.

KWIN. 2014. Kwantitatieve Informatie Veehouderij 2014-2015. Wageningen UR Livestock Research, KWIN Handboek 28.

Ogink, N.W.M., G. Mol. 2002. Uitwerking van een protocol voor het meten van de geuremissie uit stallocaties en stalsystemen in de veehouderij. IMAG nota P 2002-57, 31 pp.

Ogink, N.W.M.. 2011. Protocol voor meting van geuremissie uit huisvestingssystemen in de veehouderij 2010. Rapport 491, Wageningen UR Livestock, Lelystad, The Netherlands.

Ogink, N.W.M., J. Mosquera en J.M.G. Hol. 2013. Protocol voor meting van ammoniakemissie uit huisvestingssystemen in de veehouderij 2013. Rapport 726, Wageningen UR Livestock, Lelystad, The Netherlands.

Staatscourant. 2015. Wijziging van de Regeling ammoniak en veehouderij. Staatscourant 16866,1 juli 2015.

Staatscourant. 2013. Wijziging van de Regeling geurhinder en veehouderij. Staatscourant 35929, 31 december 2013.

Wintjens, Y. 1993. Gaswasfles. In Meetmethoden $\mathrm{NH}_{3}$-emissie uit stallen. Onderzoek inzake de mesten ammoniak- problematiek in de veehouderij 16 (eds E.N.J. van Ouwerkerk), pp. 38-40. DLO, Wageningen. 


\section{Appendix 1 Photos of the farm locations}

\section{Farm location 1}

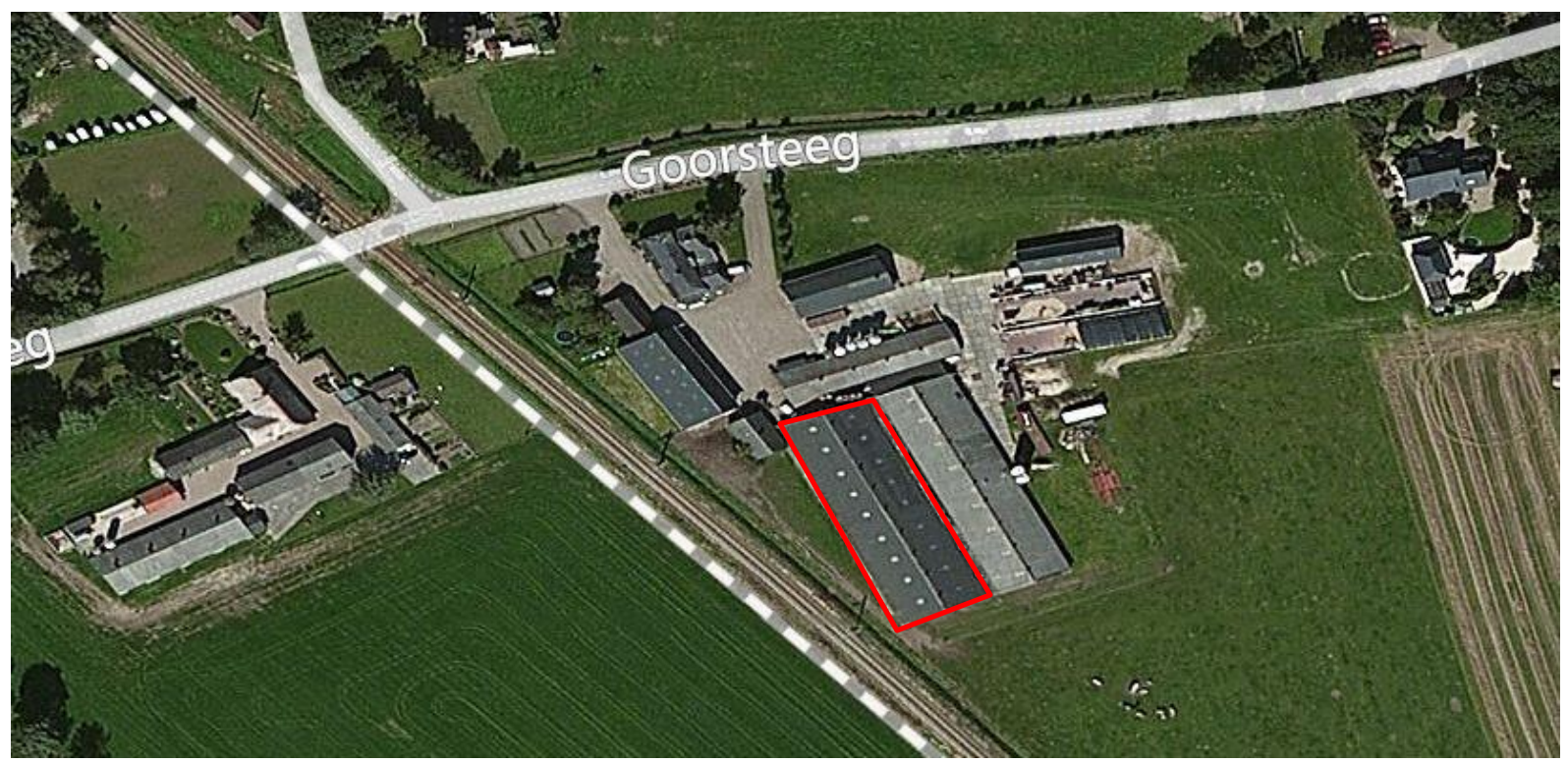

Positioning of the farm in the neighbourhood

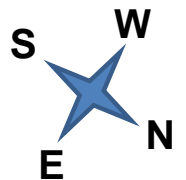

\begin{tabular}{|c|c|c|c|c|c|c|c|c|}
\hline \multicolumn{4}{|c|}{ Room 10} & \multicolumn{5}{|c|}{ Room 9} \\
\hline \multicolumn{9}{|c|}{ Hallway } \\
\hline $\begin{array}{c}\text { Room } \\
8\end{array}$ & $\begin{array}{c}\text { Room } \\
7\end{array}$ & $\begin{array}{c}\text { Room } \\
6\end{array}$ & $\begin{array}{c}\text { Room } \\
5\end{array}$ & 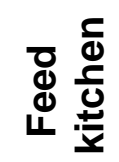 & $\begin{array}{c}\text { Room } \\
4\end{array}$ & $\begin{array}{c}\text { Room } \\
3\end{array}$ & $\begin{array}{c}\text { Room } \\
2\end{array}$ & $\begin{array}{c}\text { Room } \\
1\end{array}$ \\
\hline
\end{tabular}

Floor plan of the farm with the selected rooms. Room 1: "Groene vlag with valves"; Room 2: "Groene vlag"; Room 3: "EasyFix"; Room 4: traditional wooden slatted floor. 


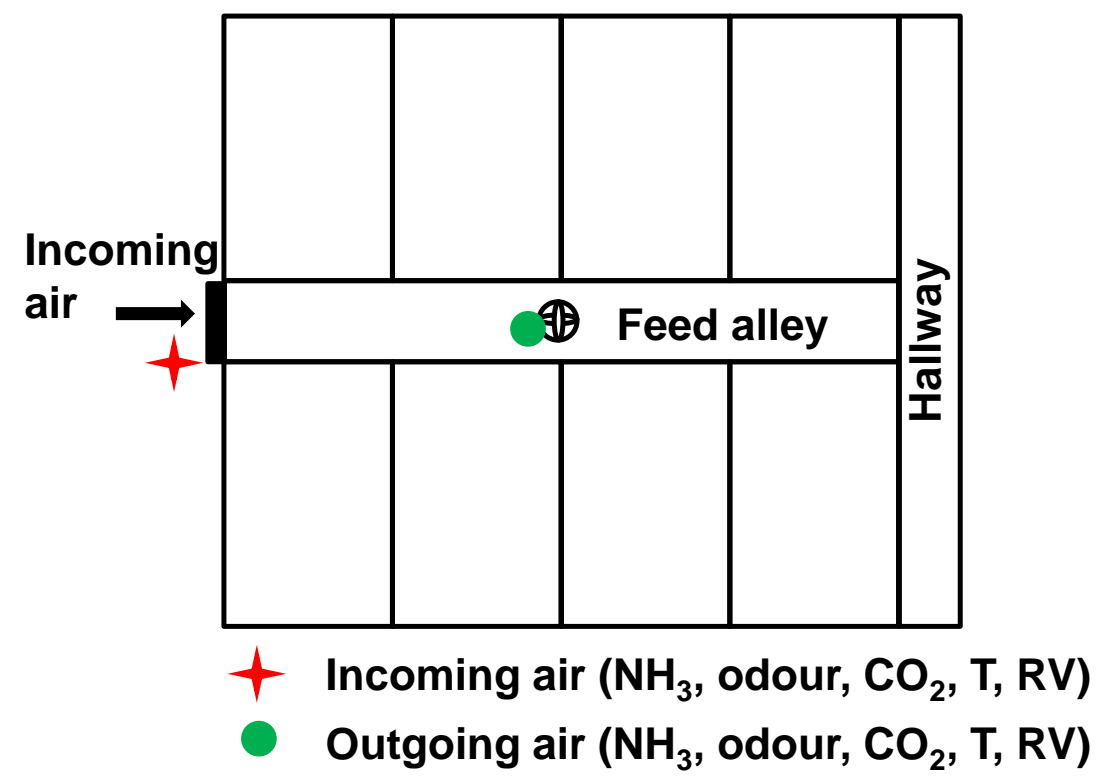

Floor plan of the measured rooms, including measurement points.

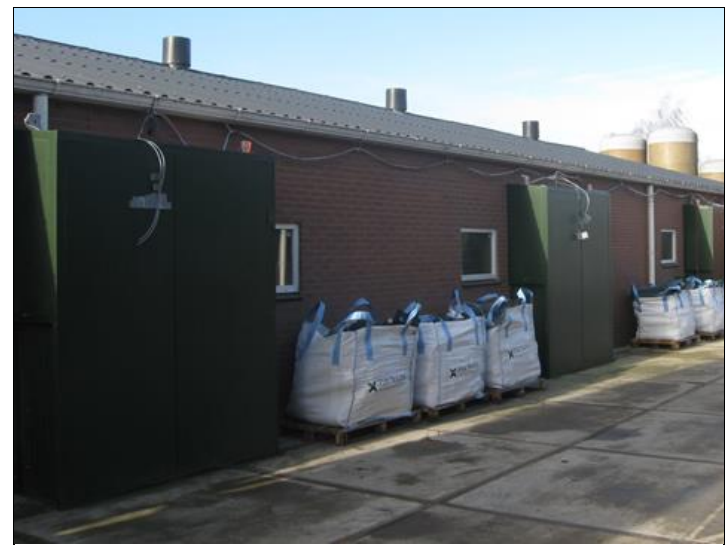

Inlet opening (outside the room)

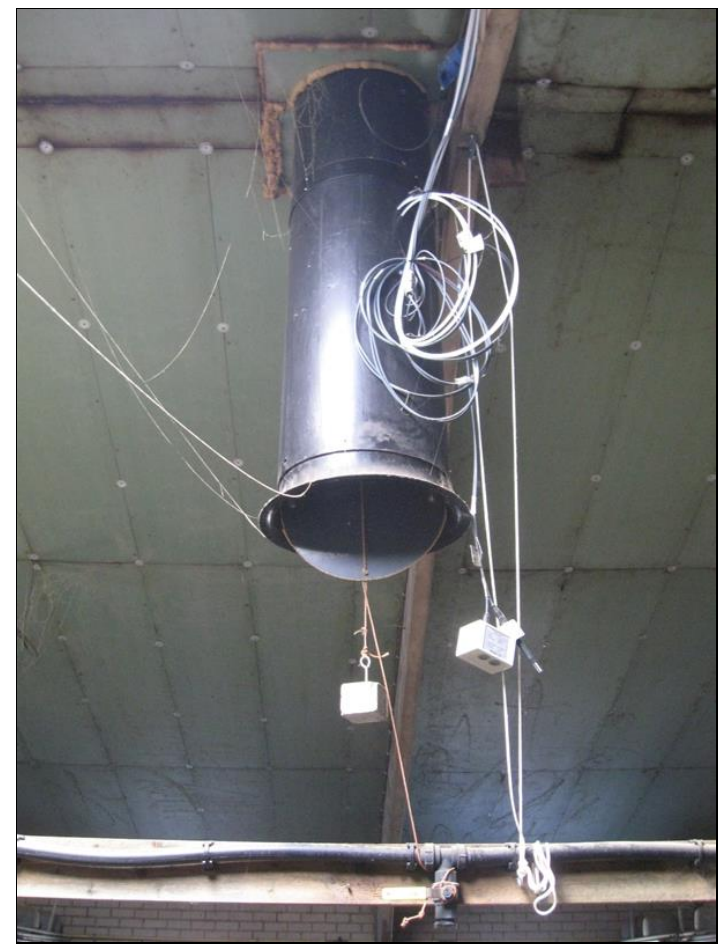

Ventilation fan

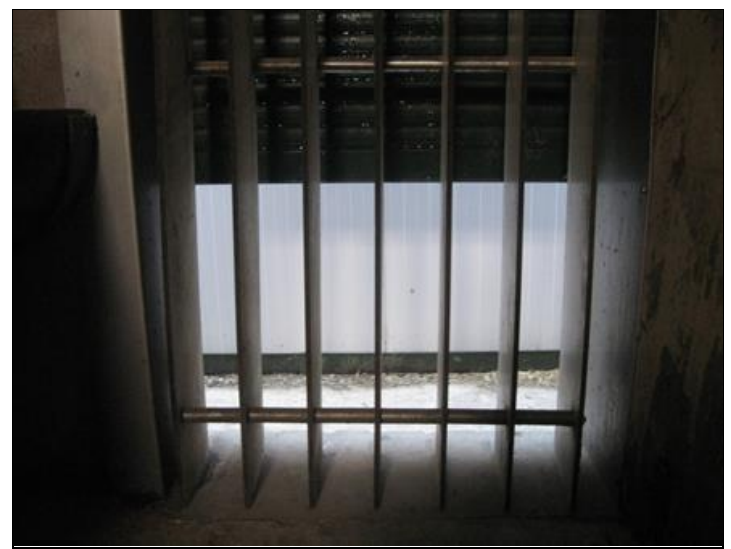

Inlet opening (inside the room)

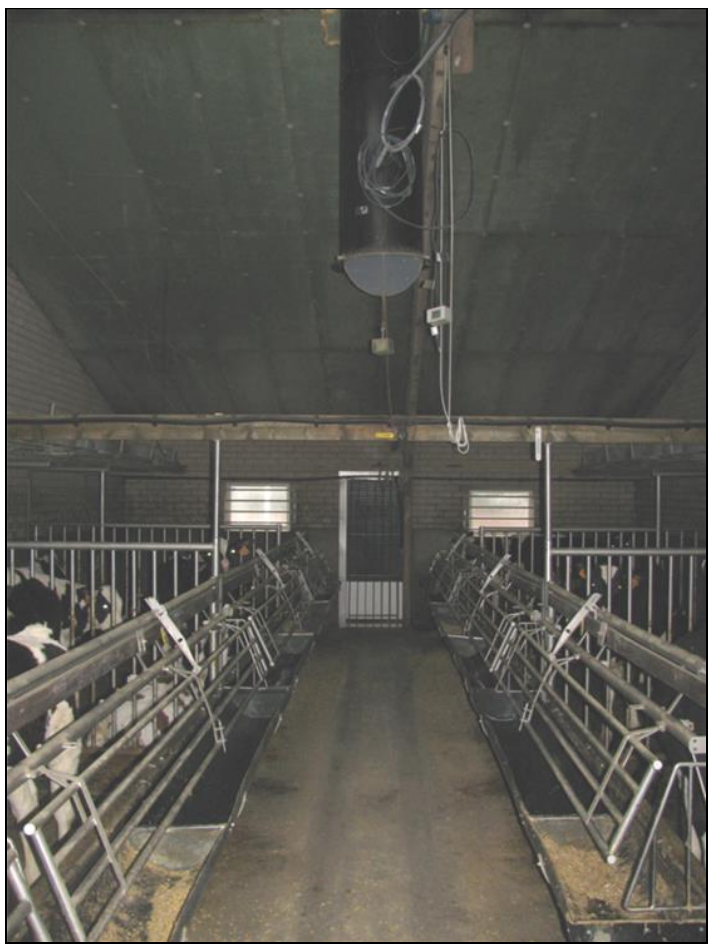

Feeding alley 


\section{Farm location 2}

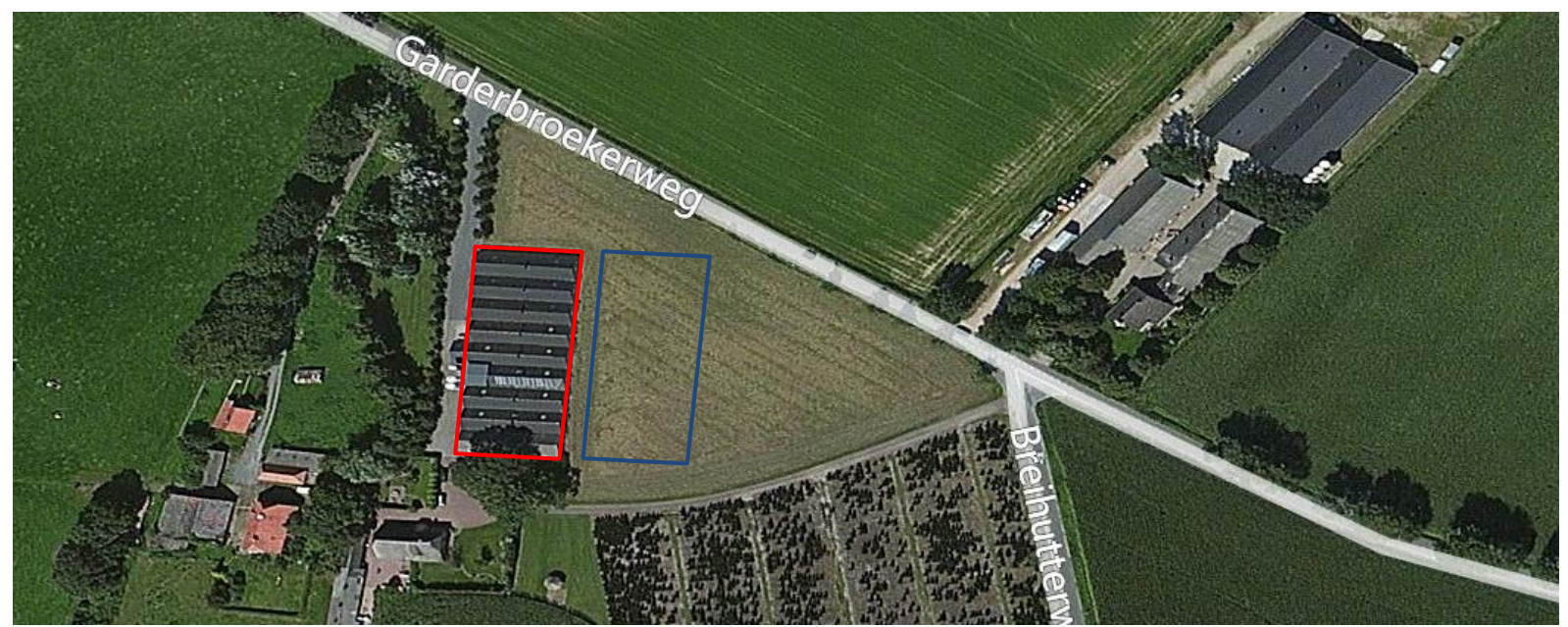

Positioning of the farm in the neighbourhood. Red: Measured building. Blue: New building

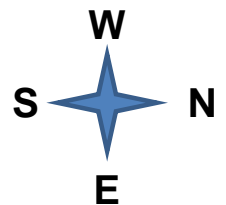

\begin{tabular}{|c|c|c|c|c|c|c|c|c|}
\hline \multicolumn{8}{|c|}{ Hallway } \\
\hline Room & Room & Room & Room & $\underset{\delta}{\frac{\delta}{5}}$ & Room & Room & Room & Room \\
1 & 2 & 3 & 4 & 5 & 6 & 7 & 8 \\
\hline
\end{tabular}

Floor plan of the farm with the selected rooms. Room 2: "Groene vlag with valves"; Room 3: "Groene vlag"; Room 5: traditional wooden slatted floor; Room 6: "EasyFix".

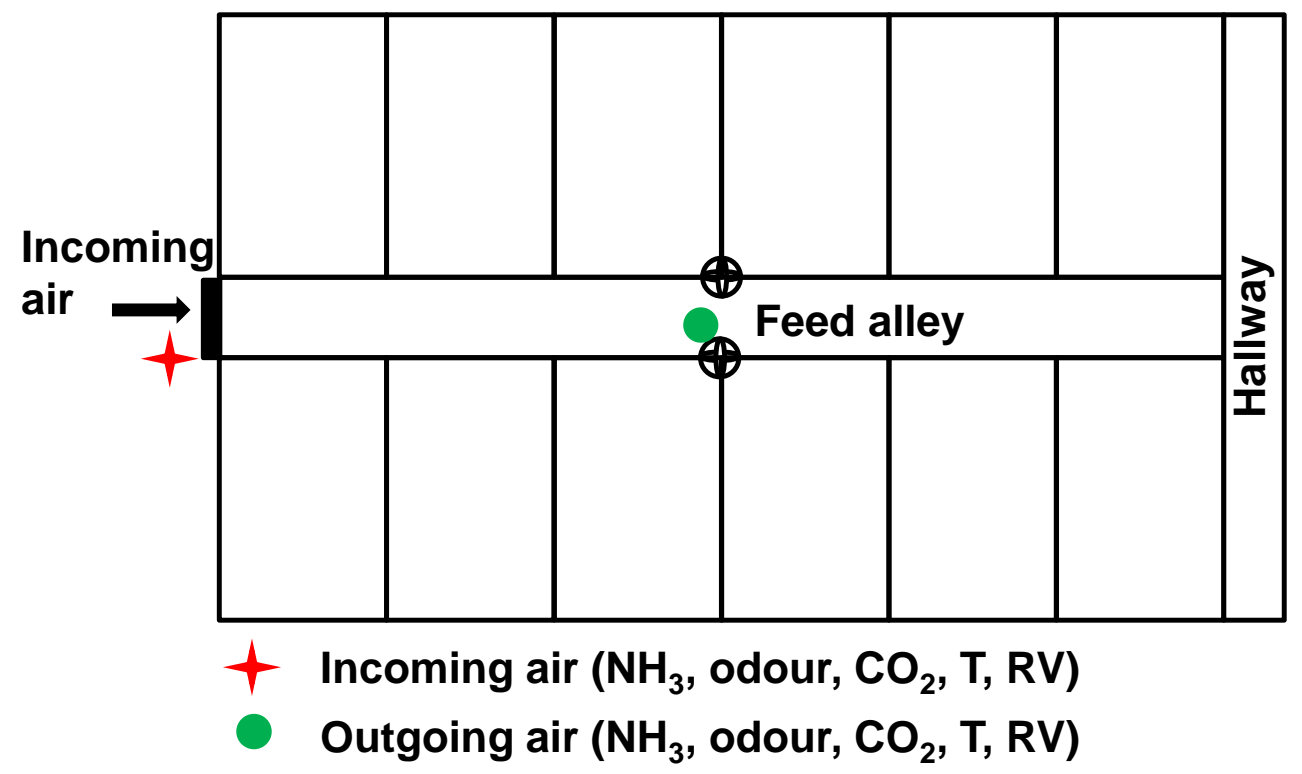

Floor plan of the measured rooms, including measurement points. 


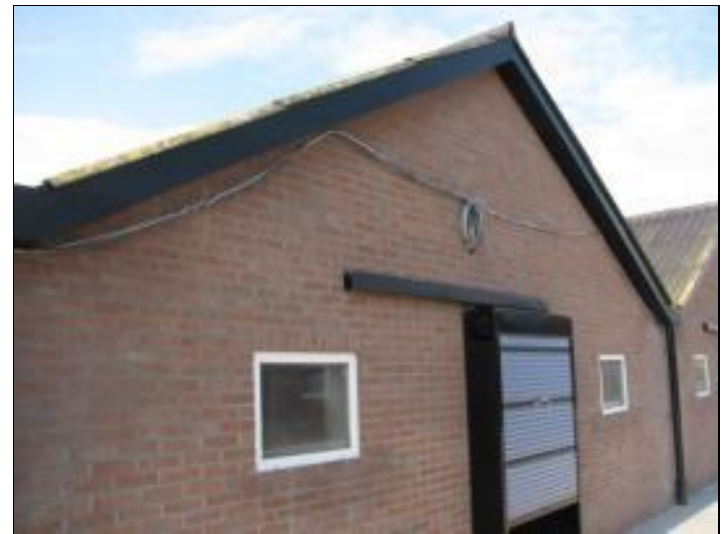

Inlet opening (outside the room)

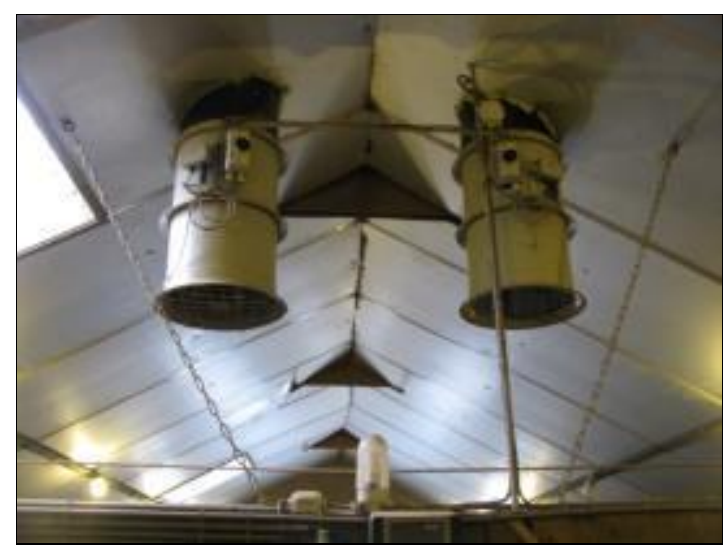

Ventilation fans

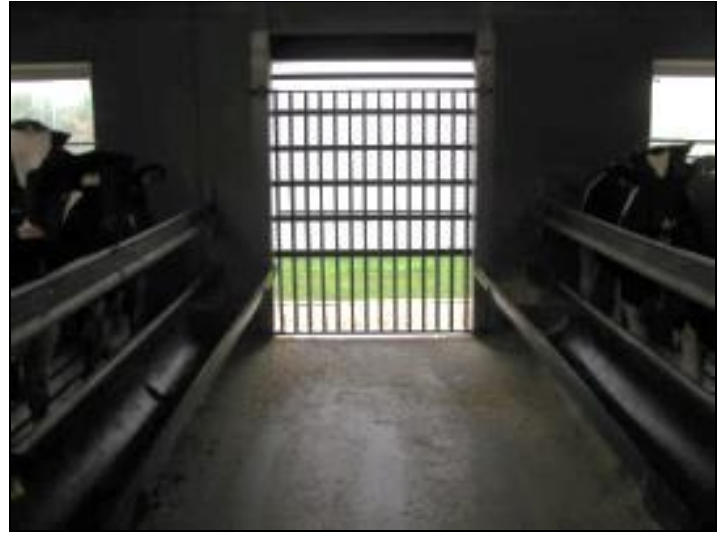

Inlet opening (inside the room)

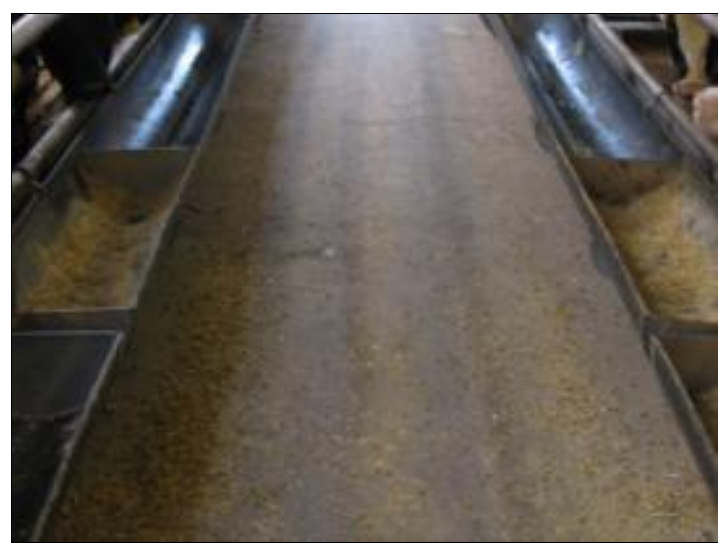

Feeding alley 


\section{Appendix 2 Veterinary care}

\section{Farm location 1, production cycle 1}

\begin{tabular}{|c|c|c|c|c|}
\hline Floor & Traditional & Easyfix & Groene vlag & Groene vlag with valves \\
\hline $\begin{array}{l}\text { Number of animals } \\
\text { treated: }\end{array}$ & 14 & 16 & 20 & 20 \\
\hline $\begin{array}{l}\text { Disease (calves } \\
\text { treated) }\end{array}$ & $\begin{array}{l}\text { Peritonitis (5) } \\
\text { Intestinal cramps (3) } \\
\text { Joint and/or claw inflammation (3) } \\
\text { Pulmonary disease (13) }\end{array}$ & $\begin{array}{l}\text { Coccidiosis (1) } \\
\text { Intestinal cramps (1) } \\
\text { diarrhoea (5) } \\
\text { Pulmonary disease (13) }\end{array}$ & $\begin{array}{l}\text { diarrhoea (1) } \\
\text { Joint and/or claw inflammation (1) } \\
\text { Pulmonary disease (19) }\end{array}$ & $\begin{array}{l}\text { Coccidiosis (1) } \\
\text { Intestinal cramps (2) } \\
\text { Joint and/or claw inflammation (1) } \\
\text { Pulmonary disease (16) }\end{array}$ \\
\hline $\begin{array}{l}\text { Used medicines } \\
\text { (calves treated) }\end{array}$ & $\begin{array}{l}\text { Bisolvon injection (1) } \\
\text { DEPOCILLINE (8) } \\
\text { DIATRIM 24\% (12) } \\
\text { Halocur (2) } \\
\text { Melovem (12) } \\
\text { Micotil } 300 \text { injection (1) } \\
\text { NUFLOR } 250 \text { ML (10) } \\
\text { Vecoxan (1) } \\
\text { Voreen Suspension (2) }\end{array}$ & $\begin{array}{l}\text { Albipen L.A. (1) } \\
\text { Bisolvon injection (1) } \\
\text { Buscopan comp injection (1) } \\
\text { DEPOCILLINE (3) } \\
\text { DIATRIM 24\% (11) } \\
\text { Halocur (3) } \\
\text { Melovem (9) } \\
\text { Micotil } 300 \text { injection (1) } \\
\text { NUFLOR } 250 \text { ML (7) } \\
\text { Voreen Suspension (1) }\end{array}$ & $\begin{array}{l}\text { Bisolvon injection (1) } \\
\text { Buscopan comp injection (1) } \\
\text { DEPOCILLINE (6) } \\
\text { DIATRIM 24\% (9) } \\
\text { Halocur (2) } \\
\text { Melovem (16) } \\
\text { Micotil } 300 \text { injection (2) } \\
\text { NUFLOR } 250 \text { ML (12) } \\
\text { Voreen Suspension (1) }\end{array}$ & $\begin{array}{l}\text { Amoxy+C Injection (1) } \\
\text { DEPOCILLINE (5) } \\
\text { DIATRIM 24\% (5) } \\
\text { Melovem (16) } \\
\text { NUFLOR } 250 \text { ML (10) }\end{array}$ \\
\hline
\end{tabular}




\section{Farm location 1, production cycle 2}

\begin{tabular}{|c|c|c|c|c|}
\hline Floor & Traditional & Easyfix & Groene vlag & Groene vlag with valves \\
\hline $\begin{array}{l}\text { Number of animals } \\
\text { treated: }\end{array}$ & 18 & 22 & 18 & 15 \\
\hline $\begin{array}{l}\text { Disease (calves } \\
\text { treated) }\end{array}$ & $\begin{array}{l}\text { Coccidiosis (2) } \\
\text { Intestinal cramps (18) } \\
\text { diarrhoea (1) }\end{array}$ & $\begin{array}{l}\text { Coccidiosis (4) } \\
\text { Joint and/or claw inflammation (2) } \\
\text { Pulmonary disease (18) } \\
\text { diarrhoea (1) }\end{array}$ & $\begin{array}{l}\text { Peritonitis (1) } \\
\text { Coccidiosis (1) } \\
\text { Joint and/or claw inflammation (2) } \\
\text { Pulmonary disease (18) }\end{array}$ & $\begin{array}{l}\text { Joint and/or claw inflammation (1) } \\
\text { Pulmonary disease (14) }\end{array}$ \\
\hline $\begin{array}{l}\text { Used medicines } \\
\text { (calves treated) }\end{array}$ & $\begin{array}{l}\text { Colfen } 300 \mathrm{mg} / \mathrm{ml} \text { (2) } \\
\text { DIATRIM 24\% (1) } \\
\text { Melovem (14) } \\
\text { MICOTIL } 300 \text { injection (5) } \\
\text { Nuflor } 250 \mathrm{ml}(2) \\
\text { Oxy LA injection (10) } \\
\text { TYLAN-200 Injection (1) } \\
\text { Vecoxan (2) }\end{array}$ & $\begin{array}{l}\text { Colfen } 300 \mathrm{mg} / \mathrm{ml} \text { (11) } \\
\text { DEPOCILLINE (3) } \\
\text { DIATRIM 24\% (1) } \\
\text { Melovem (18) } \\
\text { MICOTIL } 300 \text { injection (5) } \\
\text { Nuflor } 250 \mathrm{ml}(1) \\
\text { Oxy LA INJ (6) } \\
\text { TYLAN-200 injection (1) } \\
\text { Vecoxan (4) }\end{array}$ & $\begin{array}{l}\text { Colfen } 300 \mathrm{mg} / \mathrm{ml} \text { (9) } \\
\text { DEPOCILLINE (1) } \\
\text { DIATRIM 24\% (1) } \\
\text { Melovem (18) } \\
\text { MICOTIL } 300 \text { injection (6) } \\
\text { Nuflor } 250 \mathrm{ml}(4) \\
\text { Oxy LA INJ (8) } \\
\text { TYLAN-200 injection (2) } \\
\text { Vecoxan (1) }\end{array}$ & $\begin{array}{l}\text { Bisolvon injection (1) } \\
\text { Colfen } 300 \mathrm{mg} / \mathrm{ml} \text { (5) } \\
\text { Melovem (14) } \\
\text { MICOTIL } 300 \text { injection (4) } \\
\text { Nuflor } 250 \mathrm{ml}(1) \\
\text { Oxy LA injection (1) } \\
\text { TYLAN-200 injection (3) } \\
\text { Voreen suspension (1) }\end{array}$ \\
\hline
\end{tabular}




\section{Farm location 2, production cycle 1}

\begin{tabular}{|c|c|c|c|c|}
\hline Floor & Traditional & Easyfix & Groene vlag & Groene vlag with valves \\
\hline $\begin{array}{l}\text { Number of animals } \\
\text { treated: }\end{array}$ & 39 & 41 & 46 & 48 \\
\hline $\begin{array}{l}\text { Disease (calves } \\
\text { treated) }\end{array}$ & $\begin{array}{l}\text { Pulmonary disease (36) } \\
\text { Intestinal cramps (8) } \\
\text { Other inflammations (1) }\end{array}$ & $\begin{array}{l}\text { Pulmonary disease (37) } \\
\text { Intestinal cramps (6) }\end{array}$ & $\begin{array}{l}\text { Pulmonary disease (46) } \\
\text { Intestinal cramps ( } 3 \text { ) }\end{array}$ & $\begin{array}{l}\text { Pulmonary disease (47) } \\
\text { Joint and leg inflammations ( } 1 \text { ) } \\
\text { Intestinal cramps (4) }\end{array}$ \\
\hline $\begin{array}{l}\text { Used medicines } \\
\text { (calves treated) }\end{array}$ & $\begin{array}{l}\text { AA Trim (2) } \\
\text { AMPI-JECT 15\% (1) } \\
\text { Buscopan comp. Injection(4) } \\
\text { DEPOCILLINE (1) } \\
\text { DOFATRIM-JECT (3) } \\
\text { Draxxin (3) } \\
\text { NOVEM (19) } \\
\text { NUFLOR 100 ML (11) } \\
\text { Resflor (27) } \\
\text { Tilmodil (6) } \\
\text { Voreen Suspension (5) } \\
\text { Zactran (2) }\end{array}$ & $\begin{array}{l}\text { AA Trim (2) } \\
\text { Buscopan comp. Injection (2) } \\
\text { DEPOCILLINE (1) } \\
\text { DOFATRIM-JECT (2) } \\
\text { Draxxin (2) } \\
\text { NOVEM (22) } \\
\text { NUFLOR } 100 \text { ML (18) } \\
\text { Resflor (18) } \\
\text { Tilmodil (11) } \\
\text { Voreen Suspension (3) } \\
\text { Zactran (1) }\end{array}$ & $\begin{array}{l}\text { AA Trim (1) } \\
\text { Buscopan comp. Injection (2) } \\
\text { Draxxin (1) } \\
\text { GENTAJECT } 10 \% \text { (1) } \\
\text { NOVEM (23) } \\
\text { NUFLOR } 100 \text { ML (23) } \\
\text { Resflor (28) } \\
\text { Tilmodil (27) } \\
\text { Voreen Suspension (12) } \\
\text { Zactran (1) }\end{array}$ & $\begin{array}{l}\text { AA Trim (3) } \\
\text { AMPI-JECT 15\% (1) } \\
\text { Buscopan comp. Injection (1) } \\
\text { DEPOCILLINE (1) } \\
\text { NOVEM (20) } \\
\text { NUFLOR } 100 \text { ML (19) } \\
\text { Resflor (29) } \\
\text { Tilmodil (18) } \\
\text { Voreen Suspension (5) } \\
\text { Zactran (1) }\end{array}$ \\
\hline
\end{tabular}




\section{Farm location 2, production cycle 2}

\begin{tabular}{|c|c|c|c|c|}
\hline Floor & Traditional & Easyfix & Groene vlag & Groene vlag with valves \\
\hline $\begin{array}{l}\text { Number of animals } \\
\text { treated: }\end{array}$ & 28 & 54 & 18 & 15 \\
\hline $\begin{array}{l}\text { Disease (calves } \\
\text { treated) }\end{array}$ & $\begin{array}{l}\text { Pulmonary disease (28) } \\
\text { Intestinal cramps (1) } \\
\text { Other inflammations (2) }\end{array}$ & $\begin{array}{l}\text { Pulmonary disease (52) } \\
\text { Joint and/or leg inflammations (1) } \\
\text { Lower growth rate (4)Intestinal } \\
\text { cramps (5) } \\
\text { Other inflammations (2) }\end{array}$ & $\begin{array}{l}\text { Pulmonary disease (16) } \\
\text { Intestinal cramps (3) }\end{array}$ & $\begin{array}{l}\text { Pulmonary disease (12) } \\
\text { Lower growth rate (1)Intestinal cramps } \\
(5) \\
\text { Other inflammations (1) }\end{array}$ \\
\hline $\begin{array}{l}\text { Used medicines } \\
\text { (calves treated) }\end{array}$ & $\begin{array}{l}\text { Buscopan comp. Injection (1) } \\
\text { Dexaject (7) } \\
\text { Milbosin (1) } \\
\text { NOVEM (6) } \\
\text { NUFLOR } 100 \text { ML (9) } \\
\text { Resflor (27) } \\
\text { Vetrimoxin (1) }\end{array}$ & $\begin{array}{l}\text { AA Trim (2) } \\
\text { Biodyl (4) } \\
\text { Buscopan comp. Injection (2) } \\
\text { DEPOCILINE (1) } \\
\text { Dexaject (32) } \\
\text { NOVEM (18) } \\
\text { NUFLOR } 100 \text { ML (20) } \\
\text { Pyrogenium (1) } \\
\text { Resflor (52) } \\
\text { Vetrimoxin (12) } \\
\text { VITOL-JECT FORTE (3) }\end{array}$ & $\begin{array}{l}\text { Buscopan comp. Injection (3) } \\
\text { DEPOCILINE (1) } \\
\text { Dexaject (6) } \\
\text { NOVEM (6) } \\
\text { NUFLOR } 100 \text { ML (1) } \\
\text { Resflor (14) } \\
\text { Vetrimoxin (3) }\end{array}$ & $\begin{array}{l}\text { AA Trim (1) } \\
\text { Biodyl (1) } \\
\text { Buscopan comp. Injection (4) } \\
\text { DEPOCILINE (3) } \\
\text { Dexaject (3) } \\
\text { NOVEM (5) } \\
\text { NUFLOR } 100 \text { ML (4) } \\
\text { Resflor (9) } \\
\text { vitamine B-COMPLEX pro injection (1) } \\
\text { VITOL-JECT FORTE (1) } \\
\text { Voreen Suspension (1) }\end{array}$ \\
\hline
\end{tabular}




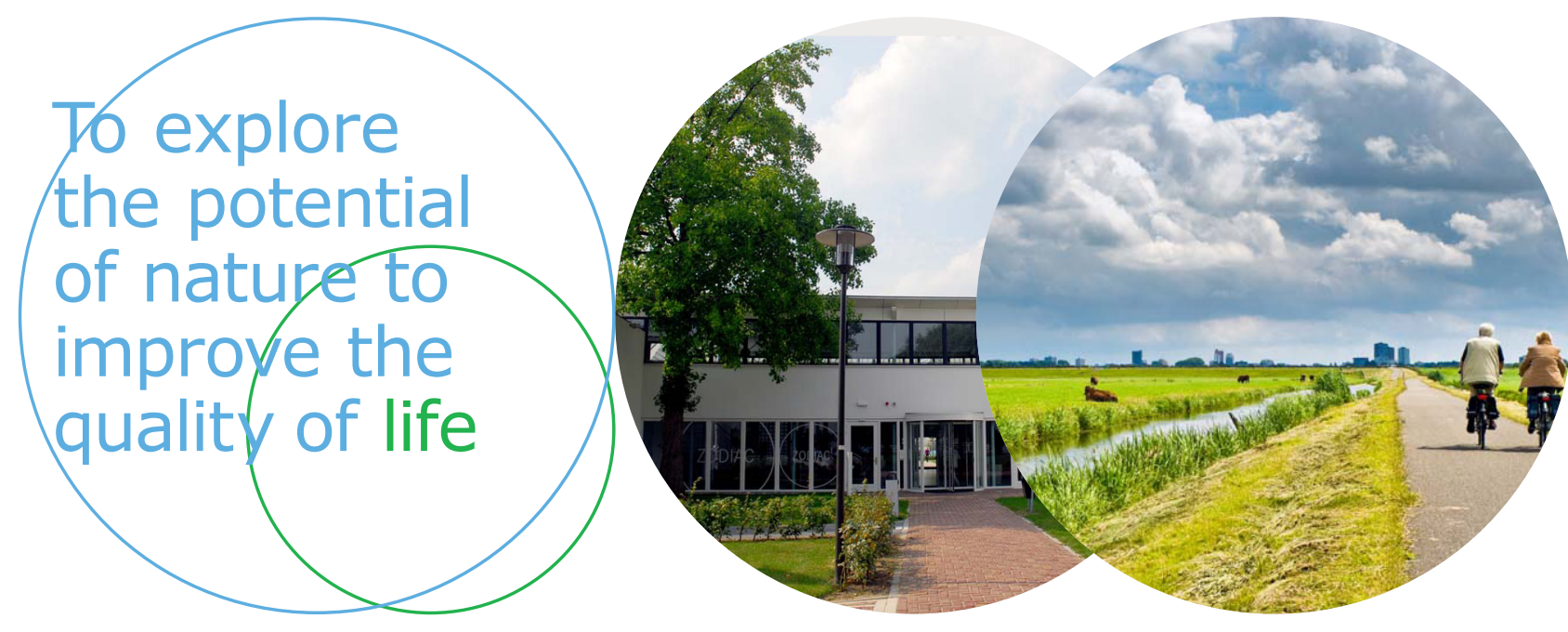

Wageningen Livestock Research P.O. Box 338

$6700 \mathrm{AH}$ Wageningen

The Netherlands

$\mathrm{T}+31(0) 317483953$

E info.livestockresearch@wur.nl

www.wur.nl/livestock-research

Wageningen Livestock Research creates science based solutions for a sustainable and profitable livestock sector. Together with our clients, we integrate scientific knowledge and practical experience to develop livestock concepts for future generations.

Wageningen Livestock Research is part of Wageningen University \& Research. Together we work on the mission: 'To explore the potential of nature to improve the quality of life'. A staff of 6,500 and 10,000 students from over 100 countries are working worldwide in the domain of healthy food and living environment for governments and the business community-at-large. The strength of Wageningen University \& Research lies in its ability to join the forces of specialised research institutes and the university. It also lies in the combined efforts of the various fields of natural and social sciences. This union of expertise leads to scientific breakthroughs that can quickly be put into practice and be incorporated into education. This is the Wageningen Approach. 